\title{
The Ngorongoro Crater as the biggest geotouristic attraction of the Gregory Rift (Northern Tanzania, Africa) - geographical setting
}

\author{
Krater Ngorongoro największą atrakcją geoturystyczną ryftu Gregory'ego \\ (północna Tanzania, Afryka) - uwarunkowania geograficzne \\ Jerzy Żaba ${ }^{1}$, Krzysztof Gaidzik ${ }^{2}$ \\ ${ }^{1,2}$ University of Silesia, Faculty of Earth Sciences, Department of Fundamental Geology, \\ ul. Będzińska 60, 41-200 Sosnowiec; \\ e-mail:1'jerzy.zaba@us.edu.pl, ${ }^{2}$ k.gaidzik@gmail.com
}
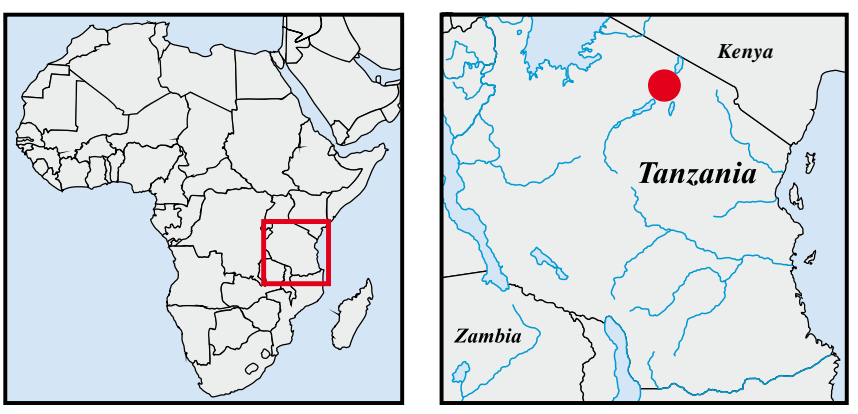

Abstract: The caldera of an extinct Ngorongoro volcano is the largest unflooded and not destroyed type of this form on Earth. The depression itself occupies an area of nearly $300 \mathrm{~km}^{2}$, while the Crater walls tower a few hundred metres (400-610 m) above the floor of the caldera. Almost all typical for East Africa plants and animals, as well as rare, endemic and often endangered species can be observed in the crater. The unique richness and diversity of natural world of the Ngorongoro Crater is caused exceptionally by favourable weather and hydrological conditions. These factors depend on local conditions, associated with significant relief of this area. Probably, the most important is the richness of the Ngorongoro Crater in water. There occur springs, perennial and seasonal rivers, marshes, swamps, as well as reservoirs of fresh and salty water. Essential is also the presence of the local autochthonous population of the Maasai people, which raises the attractiveness of that localization adding so important cultural values. Due to its unique natural and touristic values, the Ngorongoro Conservation Area (NCA) has been established in 1959. The area was also included into the UNESCO World Cultural and Natural Heritage List. This paper presents only the geographical setting of the Ngorongoro Crater, which should be understood as its morphology, hydrological and climatic conditions, wildlife and indigenous local people.

Keywords: volcanoes, Ngorongoro, Tanzania, Africa, East African Rift System, Gregory Rift, geotouristc attractions

Treść: Kaldera wygasłego wulkanu Ngorongoro stanowi największa niezalana i niezniszczona tego typu formę na Ziemi. Zagłębienie zajmuje obszar prawie $300 \mathrm{~km}^{2}$, zaśśsiany krateru wznosza się na wysokość nawet $600 \mathrm{~m}$ ponad jego dno. W jego obrębie można obserwować niemalize wszystkie, typowe dla Afryki Wschodniej rośliny i zwierzęta, a także gatunki rzadkie, endemiczne, częstokroć zagrożone wyginięciem. Bogactwo świata przyrody ożywionej cechujace krater Ngorongoro jest spowodowane wyjątkowo korzystnymi warunkami klimatycznymi i hydrologicznymi. Elementy te sa $w$ znacznym stopniu uzależnione od warunków lokalnych, zwiazanych $z$ wystepujacymi na tym obszarze deniwelacjami terenu. W obrębie kaldery Ngorongoro występuja wody stodkie i stone, zarówno plynące, jak i tworzace stałe zbiorniki o różnym charakterze. Oprócz walorów typowo przyrodniczych tego obszaru na szczególna uwagę zastuguje autochtoniczna ludność lokalna Masajów. Jej obecność podnosi w znacznym stopniu atrakcyjność analizowanego obiektu, wnoszac walory kulturowe. Ze względu na unikalne walory przyrodnicze i turystyczne w obrębie kaldery oraz na terenach przyleglych powstat w 1959 roku Obszar Chroniony Ngorongoro (NCA) o charakterze parku narodowego. Rejon ten zostat następnie wpisany na Liste Światowego Dziedzictwa Kulturalnego i Przyrodniczego UNESCO.

Slowa kluczowe: wulkany, Ngorongoro, Tanzania, Afryka, ryft Gregory'ego, wschodnioafrykański system ryftowy, atrakcje geoturystyczne

\section{Introduction}

The Ngorongoro Crater is a magical place, which attracts many visitors each year. This so-called "Natural Ark of Africa" captivates among others, living in the wild, like in the Garden of Eden, thousands of almost all of East Africa animal species. Its appearance fascinates: a huge volcanic caldera full of life seems to move the visitors into ancient times before Civilization (Fig. 1). The association with the Garden of Eden is also compounded by the archaeological discoveries of our ancestors: the remains of Homo habilis and Australopithecus boisei in the Olduvai Gorge region and hominid footprints, which moved in the upright position, from 3,6 million years ago in the Laetoli area, near the Crater.

The Ngorongoro Crater is the largest unflooded and undisturbed type of this form on Earth. The Crater walls tower almost $1.5 \mathrm{~km}$ above the rift valley and a few hundred metres above the floor of the caldera.

This work is the first of a series of three publications concerning the Ngorongoro Crater, as the greatest geotouristic attraction of the Gregory Rift, and one of the largest in the whole of East Africa. These papers result from a 1.5-monthlong expedition to Northern Tanzania in 2004 by Jerzy Żaba. The main purpose of it was the geotouristic valorization and assessment of geosites located in the area of the Gregory Rift, especially in the vicinity of the Kilimanjaro Volcano 
(Żaba 2005) and the Ngorongoro Conservation Area. This part is devoted to geographical setting of the Crater, which should be understood as its morphology, hydrological and climatic conditions, wildlife, and indigenous local people. The second part will present the position of the Ngorongoro Crater within the East African Rift System and its geological evolution (Żaba, Gaidzik 2011a). The last part will cover the tourist development and infrastructure of the area together with the resulting risks and characteristics of the geotouristic attractions of the Ngorongoro Conservation Area (Żaba, Gaidzik 2011b).

\section{Localization and morphology}

The Ngorongoro Crater is located in the northern part of Tanzania, in the Arusha province, about $90 \mathrm{~km}$ to the west of this town, in the vicinity of border with Kenya. It lies on the East African Highland, in its part called the Crater Highlands (Figs. 2, 3). This area is situated on the western, upper limbs of normal faults (gravitational in their sense of movement) strictly connected with the Gregory Rift Valley stretching out submeridionally from the Lake Eyasi in the south to the Lake Natron in the north. To the west, the Highlands are turning through fault escarpments into the Serengeti and Salei plains. From the east, the area is limited by steep walls of the Gregory Rift Valley. The Crater Highlands are rising to the height on average of about 2,000 $\mathrm{m}$ a.s.l., whereas the highest culmination in the form of the peak of the Loolmalasin volcano is reaching an altitude of 3,648 m a.s.l. (Dawson 2008). A great number of smaller or larger volcanic cones are present within the Highlands.
The Ngorongoro Crater forms the oval-shaped caldera of an extinct, vast shield volcano with the diameter of about $35 \mathrm{~km}$. This enormous depression is extending $21 \mathrm{~km}$ in the east-west direction and $17.7 \mathrm{~km}$ in the north-south direction. The extinct Ngorongoro volcano occupies an area of $304 \mathrm{~km}^{2}$, whereas the cavity is $264 \mathrm{~km}^{2}$ large. It is the largest volcanic caldera on Earth. However, when taking into account also the flooded or partly destroyed parts, the Ngorongoro Crater is on the sixth place on Earth (Pickering 1994).

The floor of the caldera is almost flat (Fig. 4). Except for isolated high points of small volcanic cones and cliff exposures of Pleistocene lake beds, local relief can be as high as $3 \mathrm{~m}$, but is typically much less. Its absolute height ranges from about 1,700 $\mathrm{m}$ a.s.l. in the vicinity of the brackish Lake Makat in the southern part of the Crater to about $1,830 \mathrm{~m}$ a.s.l. in the north-eastern part (Fig. 5; Pickering 1994). The caldera walls range in altitude from 2,280 $\mathrm{m}$ a.s.1. to 2,440 $\mathrm{m}$ a.s.l. (Pickering 1994) and tower a few hundred metres (400-610 m) above the bottom of the cavity and about 1,400 $\mathrm{m}$ above the floor of the Gregory Rift Valley, located to the east of the Crater.

Within the Ngorongoro Crater, numerous minor landforms occur, which contribute to some variety of the mainly flat area of the caldera's floor (Fig. 6). The most common are small hills, mounds and hillocks rising several dozen metres above the floor of the caldera, mainly in the northern and eastern parts. These include, i.a., the 30-mhigh Engitati hill (1,793 m a.s.l.; Tombazzi 2003), with the diameter of about $1.2 \mathrm{~km}$, located in the north-western part of the Crater. Of particular interest is the peak of this hill, which has the form of a shallow, oval-shaped hollow saucer.

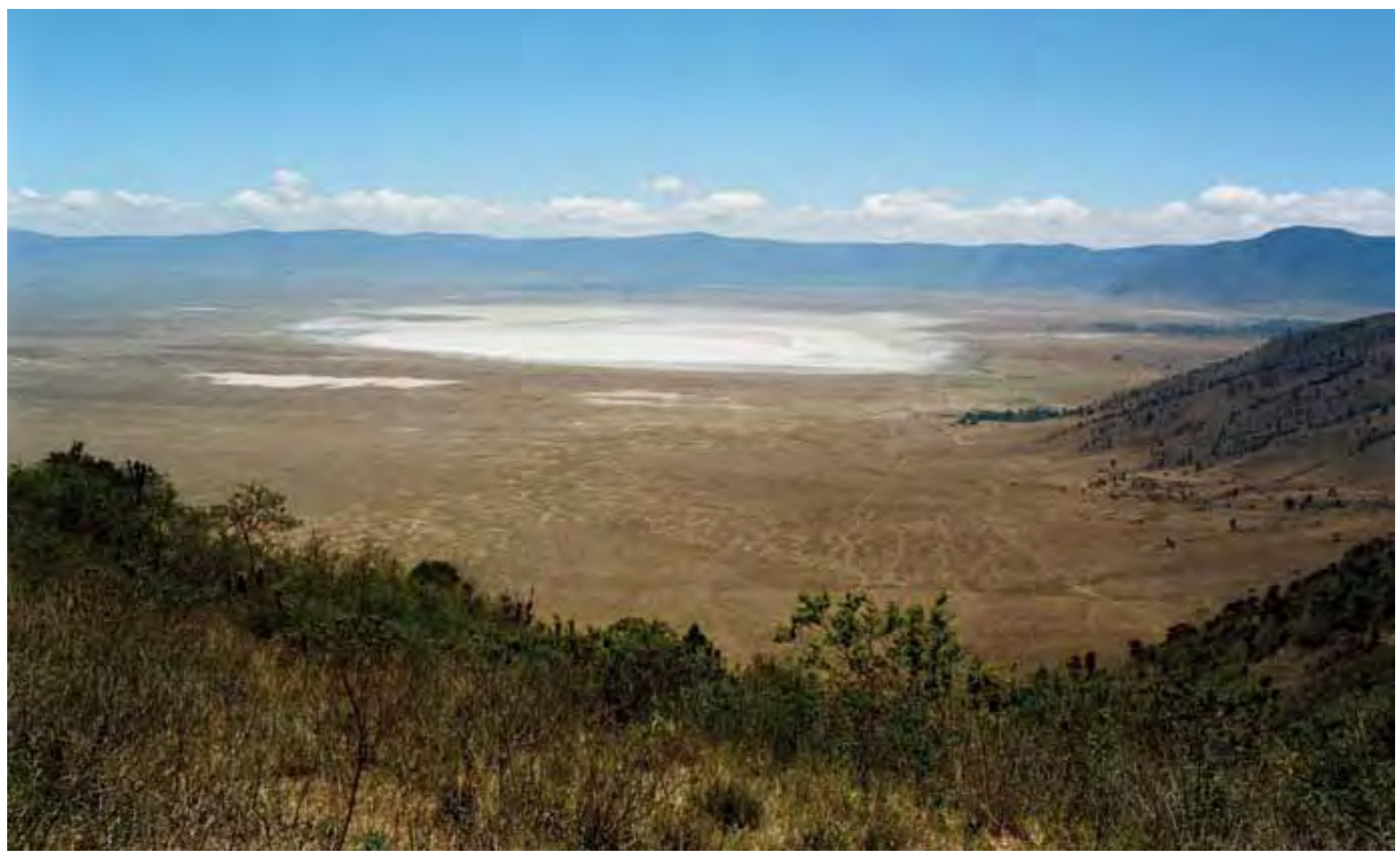

Fig. 1. The Ngorongoro Crater, view from the Crater rim (towards the North), phot. J. Żaba • Krater Ngorongoro, widok z obrzeży Krateru (ku północy), fot. J. Żaba 

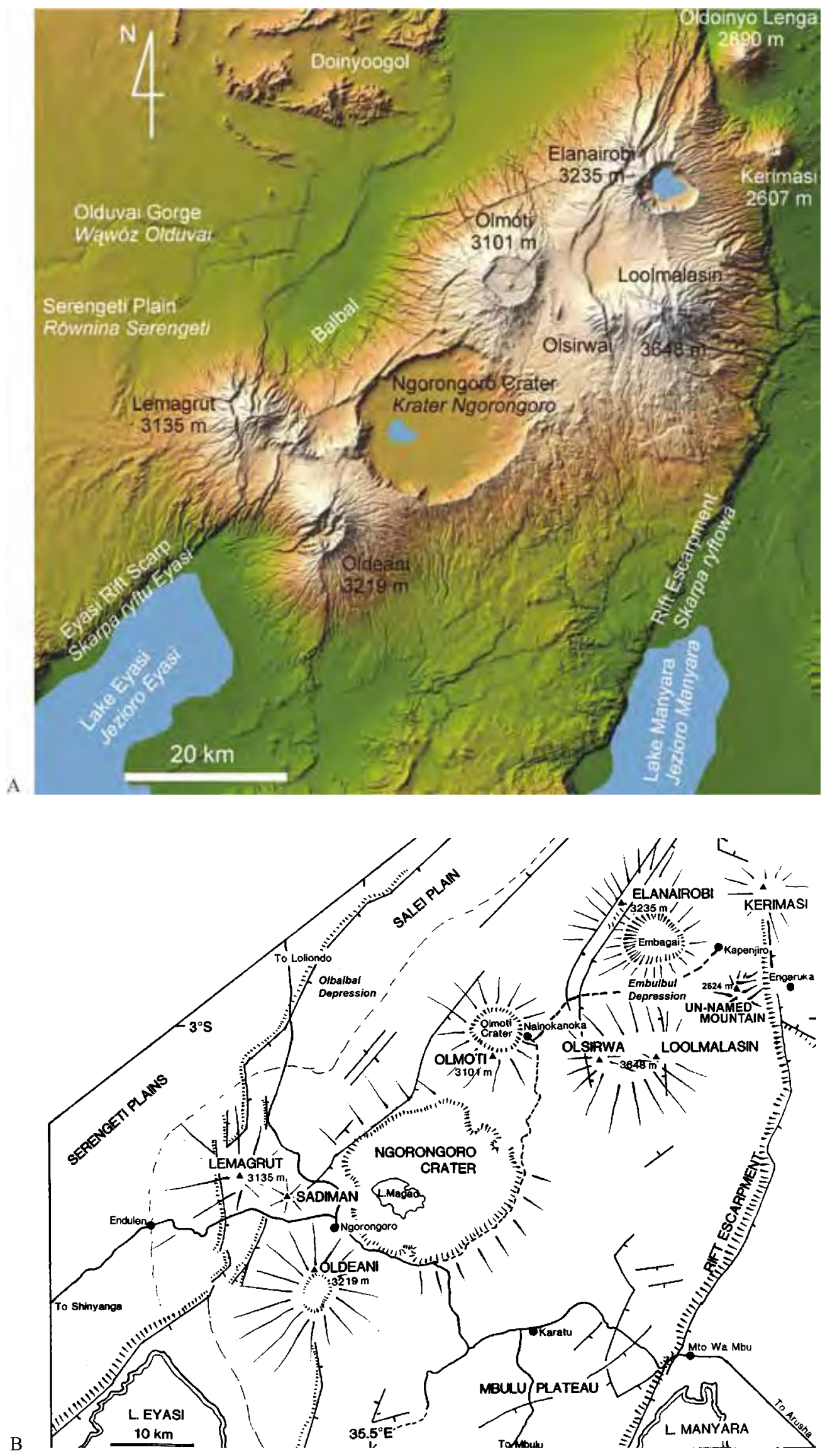

Fig. 2. The Ngorongoro Crater on the Crater Highlands: A. Topography (according to http://earthobservatory.nasa.gov/IOTD/view. php?id=4705), B. Sketch map (according to Dawson, 2008) - Krater Ngorongoro w obrębie Wyżyny Kraterów: A. Topografia (według http://earthobservatory.nasa.gov/IOTD/view.php?id=4705), B. Szkic (według Dawson 2008) 


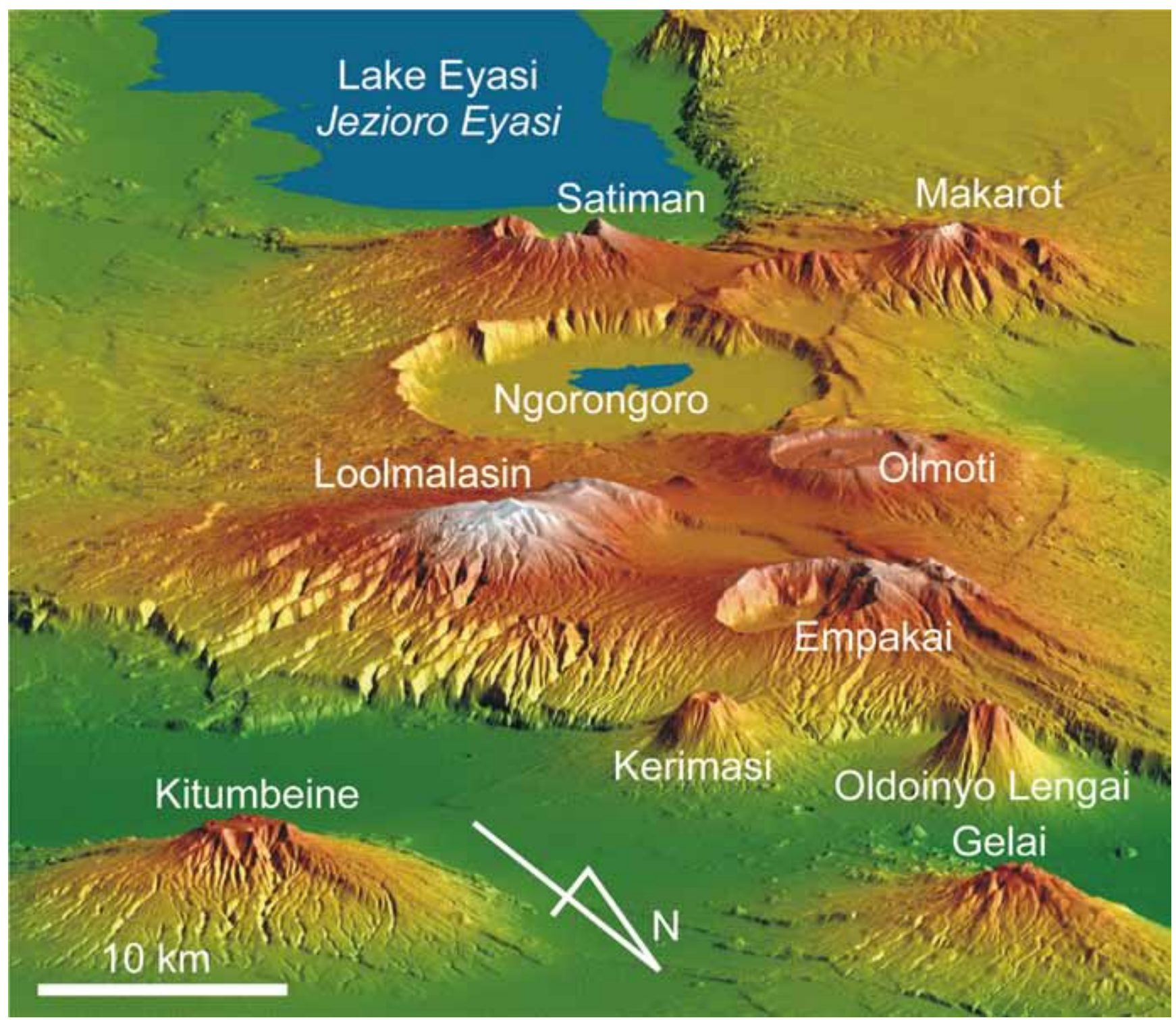

Fig. 3. The Crater Highlands, looking from the north to the south-west (according to http://earthobservatory.nasa.gov/Newsroom/NewImages/images.php3?img_id=17196) • Widok z północy ku południowemu zachodowi na Wyżynę Kraterów (według http://earthobservatory. nasa.gov/Newsroom/NewImages/images.php3?img_id=17196)

The Osilale (1,827 m a.s.1.) and Rumbe (1,914 m a.s.1.) peaks should be mentioned from other landforms of this type (Tombazzi 2003).

At the foot of the Crater walls, relatively small hills and hillocks appear. In the south-eastern part of the cavity, these minor landforms combine to create a very distinctive shelflike form at the foot of the walls, like for instance, the Keshei hills. Analogous structures in the northern part produce several, very distinct conical hills, such as the Olkaria hills (2,023 $\mathrm{m}$ and 1,931 $\mathrm{m}$ a.s.1.; Fig. 5; Tombazzi 2003). Very characteristic hummocky landscape with a vast number of very small mounds is also present in the south-western part of the caldera.

\section{Waters}

The Ngorongoro Crater is rich in water in various forms. There occur springs, perennial and seasonal rivers, marshes, swamps, as well as reservoirs of fresh and salty water. The temperature measured in all of these water resources ranges from $17^{\circ} \mathrm{C}$ in streams and cool spring heads, to $28^{\circ} \mathrm{C}$ in marsh surface waters and puddles. Total alkalinity varies from about 1.5 to $68 \mathrm{mg} / \mathrm{l}$, $\mathrm{pH}$ ranges from 6.5 to 10.4 , and conductivity varies from 125 to $11,700 \mathrm{mS} / \mathrm{cm}$. The relative cation abundances are variable within the Crater water. Waters from the southern and eastern portion of the Crater (e.g., Lerai, Ngoitokitok) tend to have a relatively greater $\mathrm{Mg}$ content than that of $\mathrm{Ca}$ compared to the northern waters (e.g., Munge and Oljoro Nyuki). These differences are reduced as the waters evaporate, with $\mathrm{Na}$ eventually dominating in all evaporated waters as $\mathrm{Ca}$ and $\mathrm{Mg}$ are removed from solution. Anions are dominated by $\mathrm{CO}_{3}^{2-}$ species in all samples, with relative abundances of $\mathrm{SO}_{4}^{2-}$ and $\mathrm{Cl}^{-}$increasing in more evaporated waters. Fluoride concentrations are quite variable, ranging from nearly $0.3 \mathrm{mg} / 1$ for the Lerai stream, to around $8.7 \mathrm{mg} / \mathrm{l}$ in the evaporatively concentrated waters 
of the Lerai Hippo Pool. Most springs and streams have $1 \mathrm{mg} / 1 \mathrm{~F}^{-}$or less in the Crater, with the exception of the Seneto spring, which has over $2 \mathrm{mg} / \mathrm{l}$ (Deocampo 2004).

The largest of these is the brackish Lake Makat (Magadi; Fig. 7), which in Maasai means salt. Although the Cl- concentration in this reservoir is not very high, just well above $100 \mathrm{mg} / \mathrm{l}$, in the dry season it amounts up to more than $3,000 \mathrm{mg} / \mathrm{l}$. The acidity of water measured by a $\mathrm{pH}$ value for this lake is very close to 10 (Deocampo 2004). The lake, depending on the season, changes much in surface it occupies. In the dry season it may completely dry up, leaving behind a very flat surface covered with salt. During the rainy season the lake could be up to $4 \mathrm{~m}$ deep.

The second largest reservoir in the Ngorongoro Crater, the Lerai Hippo Pool, is much smaller. Its Cl- concentration ranges from 20 to $120 \mathrm{mg} / \mathrm{l}$, while the $\mathrm{pH}$ is of about 9 (Fig. 8; Deocampo 2004). This freshwater lake is located south of the Lake Makat. Within the volcanic caldera floor a number of much smaller lakes occur, most of which dry up completely during the dry season (Tombazzi 2003).

There are also marshes and swamps at the Ngorongoro Crater floor being concentrated mainly in two areas: the Mandusi (Munduusi) Swamp and the Gorigor Swamp located, respectively, north and south of the Lake Makat. Both swamps, which are generally dominated by Cyperacae and other sedges, and locally by Typha (Anderson, Herlocker, 1973; Deocampo et al., 1998), are perennial features, although their sizes may fluctuate seasonally and over longer timescales. They extend nearly $10 \mathrm{~km}$ from the west to the east.
The $\mathrm{pH}$ level of water drops to about 7-8 within these swamps. These are much more acidic conditions than those of waters from other lakes of the area (Deocampo 2004).

The Crater walls are cut by deep valleys, mainly in the north of the Ngorongoro, produced by perennial and seasonal streams flowing from the Crater Highlands (Fig. 5). Two rivers, Munge and Oljoro Nyuki, enter the depression through incised channels in the NE crater wall. The sources of these streams originate to the NE of Ngorongoro, from springs in the Olmoti Crater and the Olsirwa highlands, respectively. Also the Layanai River, which flows into the caldera in the NW side of it, begins at the foot of the Olmoti Crater. The Mandusi Swamp in the north is fed perenially and periodically, respectively, by the Munge and Layanai rivers. The Oljoro Nyuki River feeds ephemerally the larger Gorigor Swamp in the south (Fig. 5). In the south-western part, there are several small streams flowing from the Crater rim: the Ende, Olawara and Lairatati streams. They all have their mouths in the Lerai Forest. In most rivers, the $\mathrm{pH}$ ranges from 7 to 8 , while the salinity increases from the spring areas to their inflows to the water reservoirs, being strictly related to evaporation (Deocampo 2004).

The largest spring of the Ngorongoro Crater is the Koitoktok (Ngoitokitok) Spring, a perennial spring, which discharges over 4.5 million litres per day (4,500 cubic metres per day). Located in the southern part of the Ngorongoro Crater, the spring feeds the Gorigor Swamp. Due to the high yield of this spring, it is of fundamental importance for existence of the Maasai people and their pastoral activity in the area.

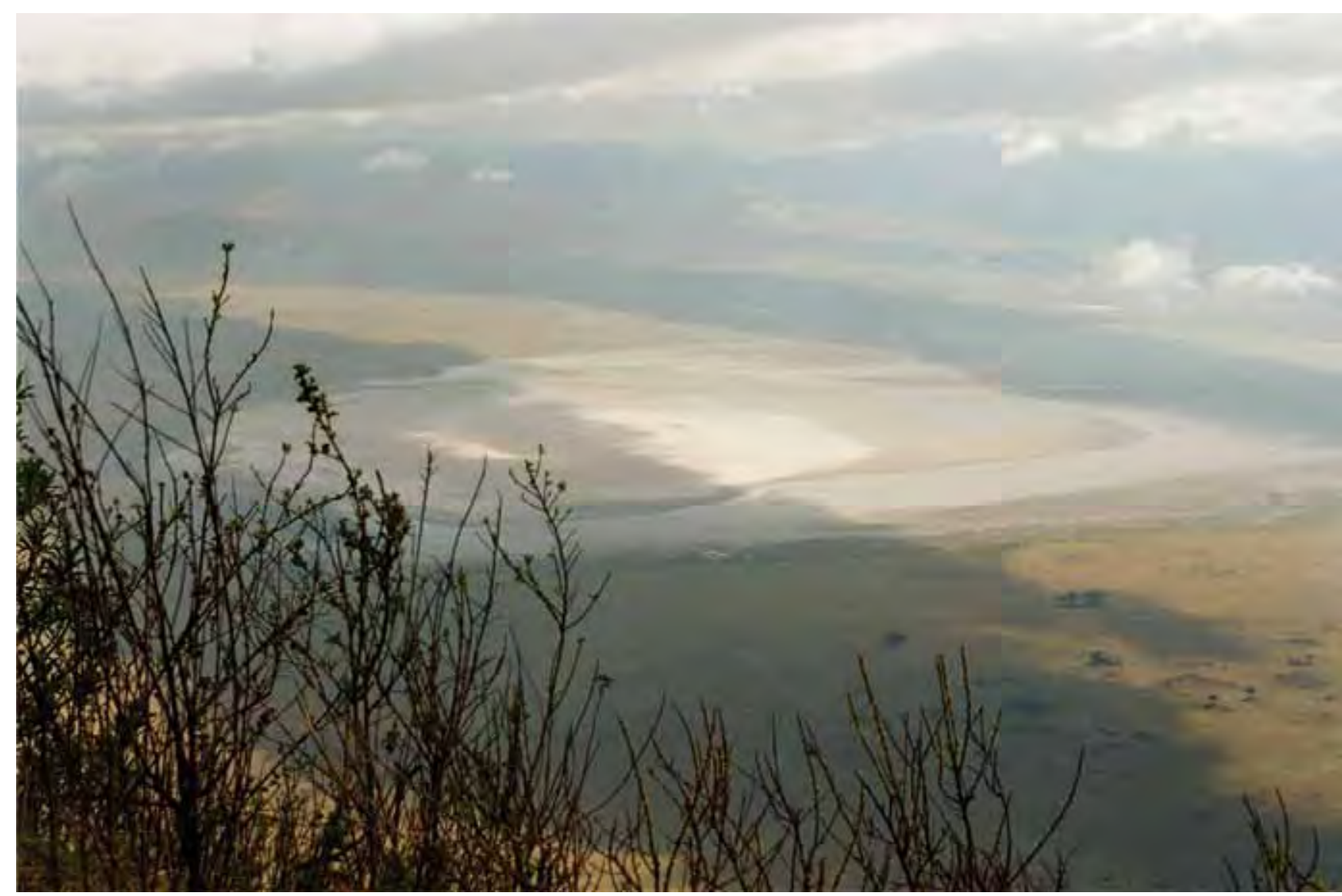

Fig. 4. Flat surface of the floor of the Ngorongoro Crater, phot. J. Żaba • Płaskie dno krateru Ngorongoro, fot. J. Żaba 


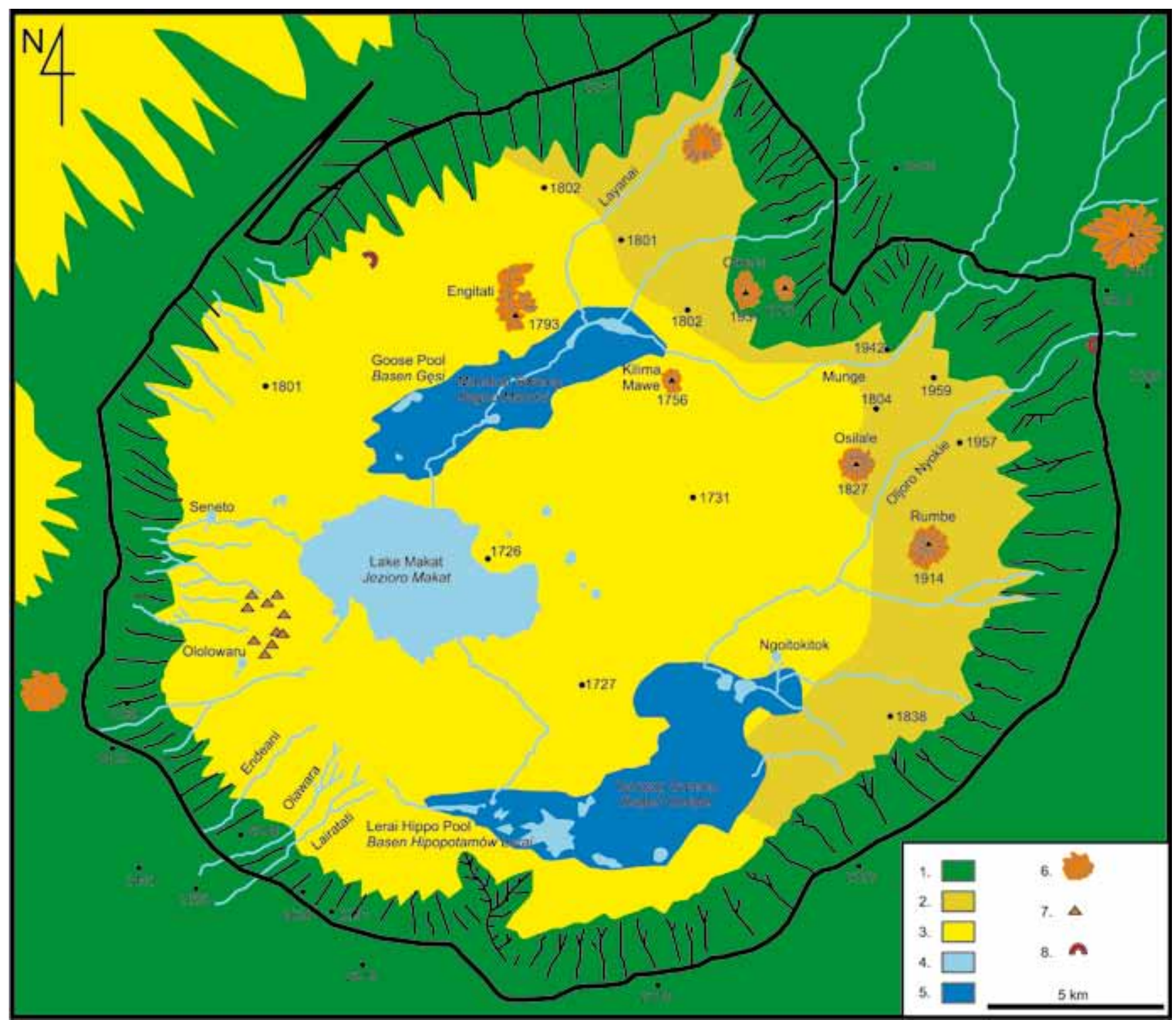

Fig. 5. Topography of the Ngorongoro Crater (according to Tombazzi, 2003, modified and supplemented) 1 - the Ngorongoro Crater walls and the caldera Highlands area, 2 - hillocky area on the floor of the Ngorongoro Crater, 3 - flat area, 4 - water/lakes, 5 - swamp, 6 - hills, 7 - mounds build of lava blocks, 8 - quarry - Topografia krateru Ngorongoro (według Tombazzi 2003, zmienione i uzupełnione). 1 - ściany krateru Ngorongoro i obszar Wyżyny Kraterów, 2 - pagórkowaty teren na dnie krateru, 3 - niemalże płaski teren, 4 - woda/ jeziora, 5 - bagna, 6 - wzniesienia, 7 - niewielkie wzniesienia zbudowane z bloków lawy, 8 - kamieniołom

Another, also quite important spring commonly used by the Maasai people, called the Seneto Spring, is located in the western part of the caldera. Relatively rich in fluoride waters of this spring feed the Lake Makat. Spring water in the Ngorongoro Crater has the lowest salinity of all the waters in this area. The $\mathrm{Cl}$ - concentration does not exceed $10 \mathrm{mg} / \mathrm{l}$. The $\mathrm{pH}$ is close to the values obtained for river waters from this area and ranges from 7 to 8 , exceptionally dropping to 6.5 (Deocampo 2004).

\section{Climate}

The Ngorongoro Crater climate varies considerably due to the range in relief and the dynamics of its air masses. Two seasons are indicated in this area: the dry season, lasting from mid-May to mid-November, and rainy season - in the second half of the year (rains occur in two periods: November-December and February-April). At the local scale, the climate is strongly influenced by very large differences in height between the floor of the caldera and the peak parts (the Crater rim). In the summit parts of the Ngorongoro Crater, on the Crater rim, as well as in the forests on the slopes of the caldera, the humid climate characterized by foggy weather dominates, with the highest precipitation of over 1,000 mm/year (Figs. 9, 10; Deocampo 2004). Inside the caldera, the climate is much drier. Semiarid plains dominate at the caldera's floor, where the temperature during the day can vary widely from $2{ }^{\circ} \mathrm{C}$ to about $35^{\circ} \mathrm{C}$. The precipitation at the bottom is about half as much as on the Crater rim, for instance, for the Lerai Forest it ranges between 400 and $850 \mathrm{~mm} /$ year, averaging $541 \mathrm{~mm} /$ year (Deocampo 2004). The amount of precipitation also varies for the Crater walls. 


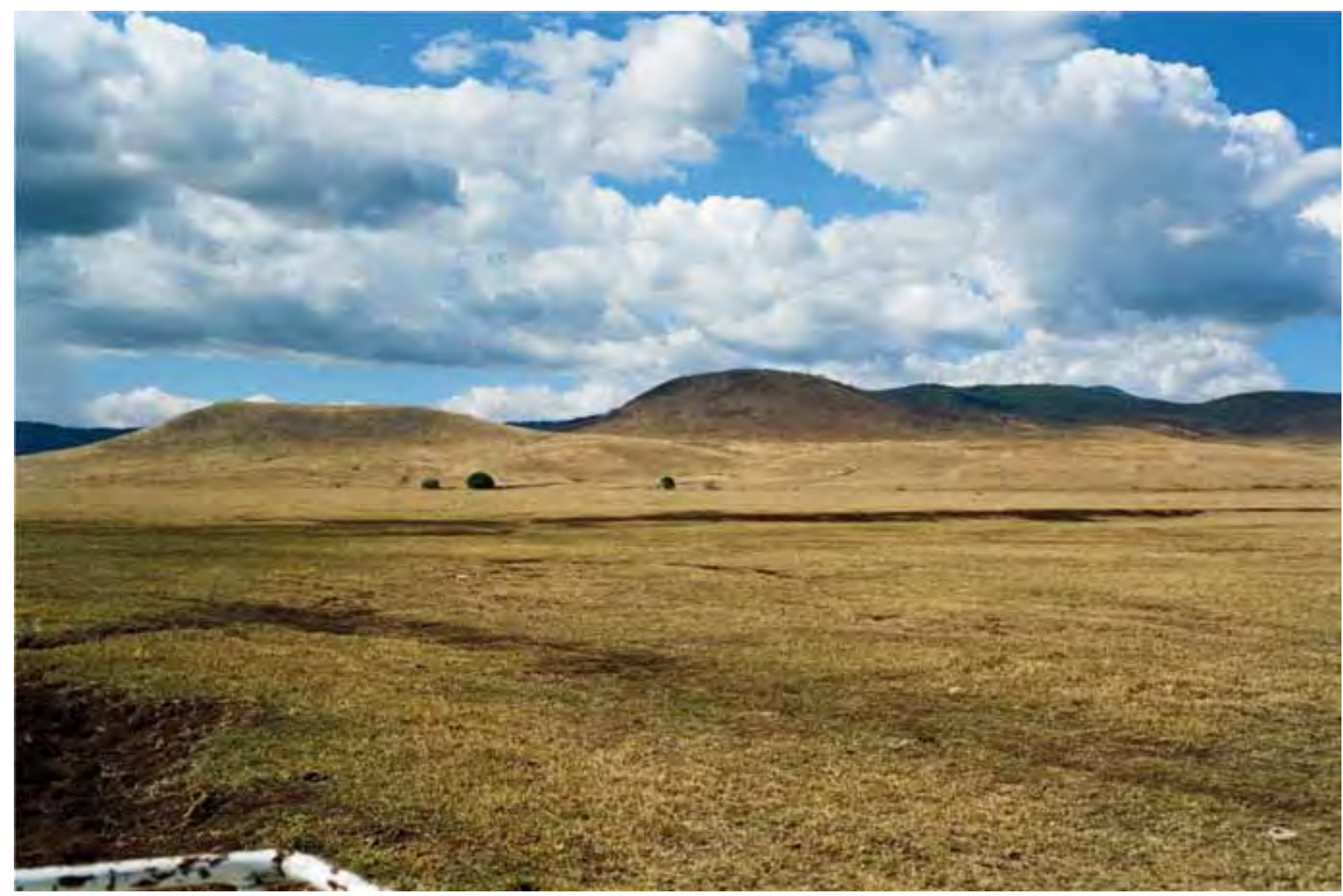

Fig. 6. Hummocky landscape of the Crater floor, phot. J. Żaba • Pagórkowaty krajobraz dna krateru, fot. J. Żaba.

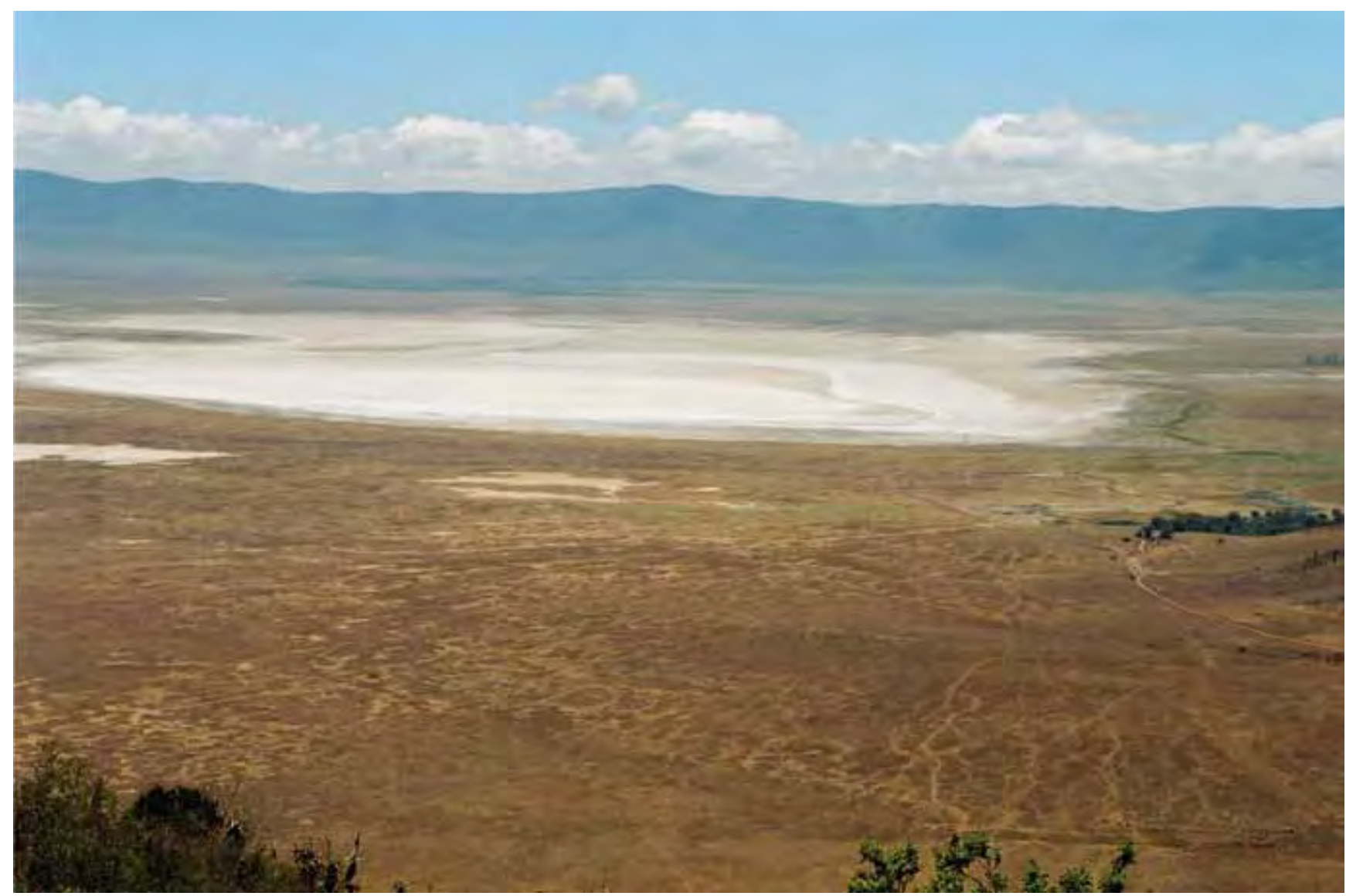

Fig. 7. Brackish Lake Makat, phot. J. Żaba • Brakiczne jezioro Makat, fot. J. Żaba 


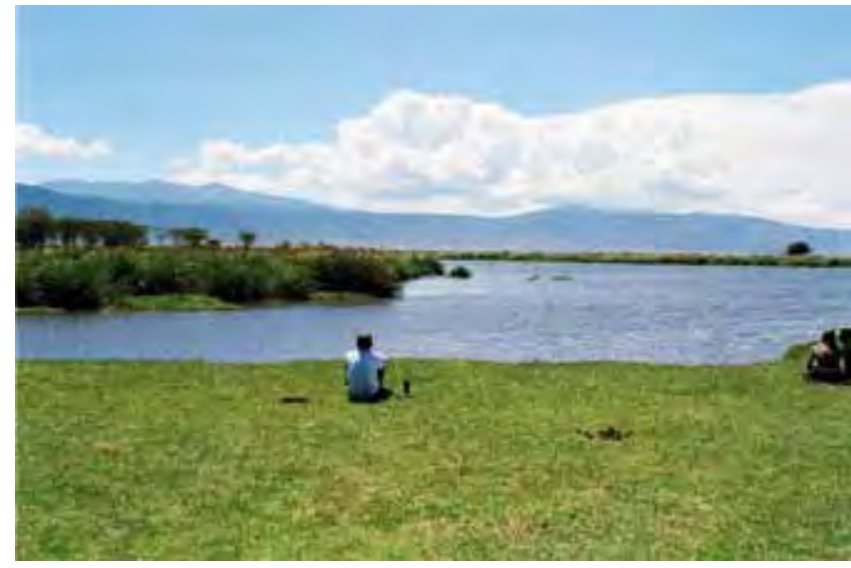

Fig. 8. Freshwater Lerai Hippo Pool, phot. J. Żaba • Słodkowodny Basen Hipopotamów, fot. J. Żaba

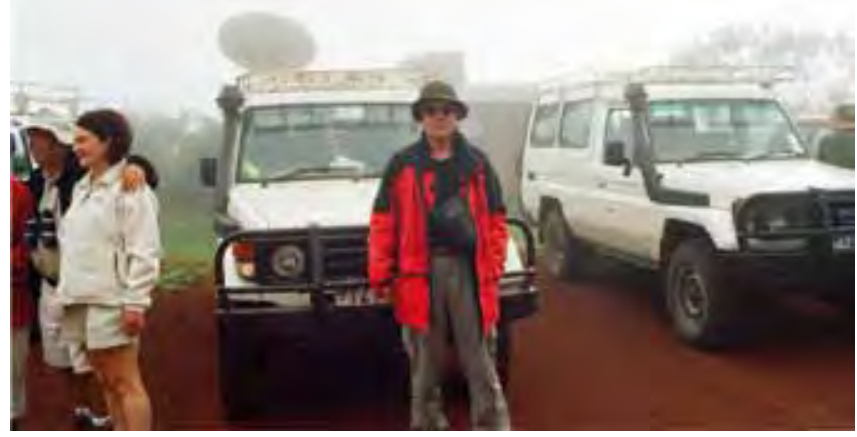

Fig. 9. Foggy weather on the Crater rim, phot. J. Żaba • Mglista pogoda na obrzeżach krateru, fot. J. Żaba
Most rain, in the amount of 800-1200 mm/year, receive forested, steep, eastern slopes of the Crater, while much less steep western ones receive only $400-600 \mathrm{~mm}$ of precipitation per year (UNESCO/IUCN 2008).

\section{Flora and fauna}

The Ngorongoro Crater, due to the unprecedented richness and diversity of the natural world (see Tab. 1,2), is defined as "the natural ark of Africa", "the sanctuary of Africa's wildlife", "microcosm of the Serengeti Plains", and even a selfcontained ecosystem. This area stands out because of the unique variety of both its flora and fauna.

The Ngorongoro Crater is located within two biogeographical provinces: the East African Woodland and Savanna. However, the variations in climate, landforms and altitude have resulted in several overlapping ecosystems and distinct habitats (Fig. 11).

The scrub heath, montane long grasslands, high open moorland and the remains of dense evergreen montane forests cover the steep slopes of the Ngorongoro Crater (Figs. 11, 12). Highland trees include: peacock flower Albizzia gummifera, yellowwood Podocarpus latifolia, red thorn Acacia lahai, Hagenia abyssinica, and sweet olive Olea chrysophylla (Tab. 1; UNESCO/IUCN 2008). The Crater walls covered with grassland and bushland are dotted with isolated Euphorbia bussei trees (Estes et al. 2006). Critical for protecting the watershed are the upland woodlands of red thorn Acacia lahai and gum acacia Acacia seyal (Kayera 1988, vide UNESCO/ IUCN 2008).

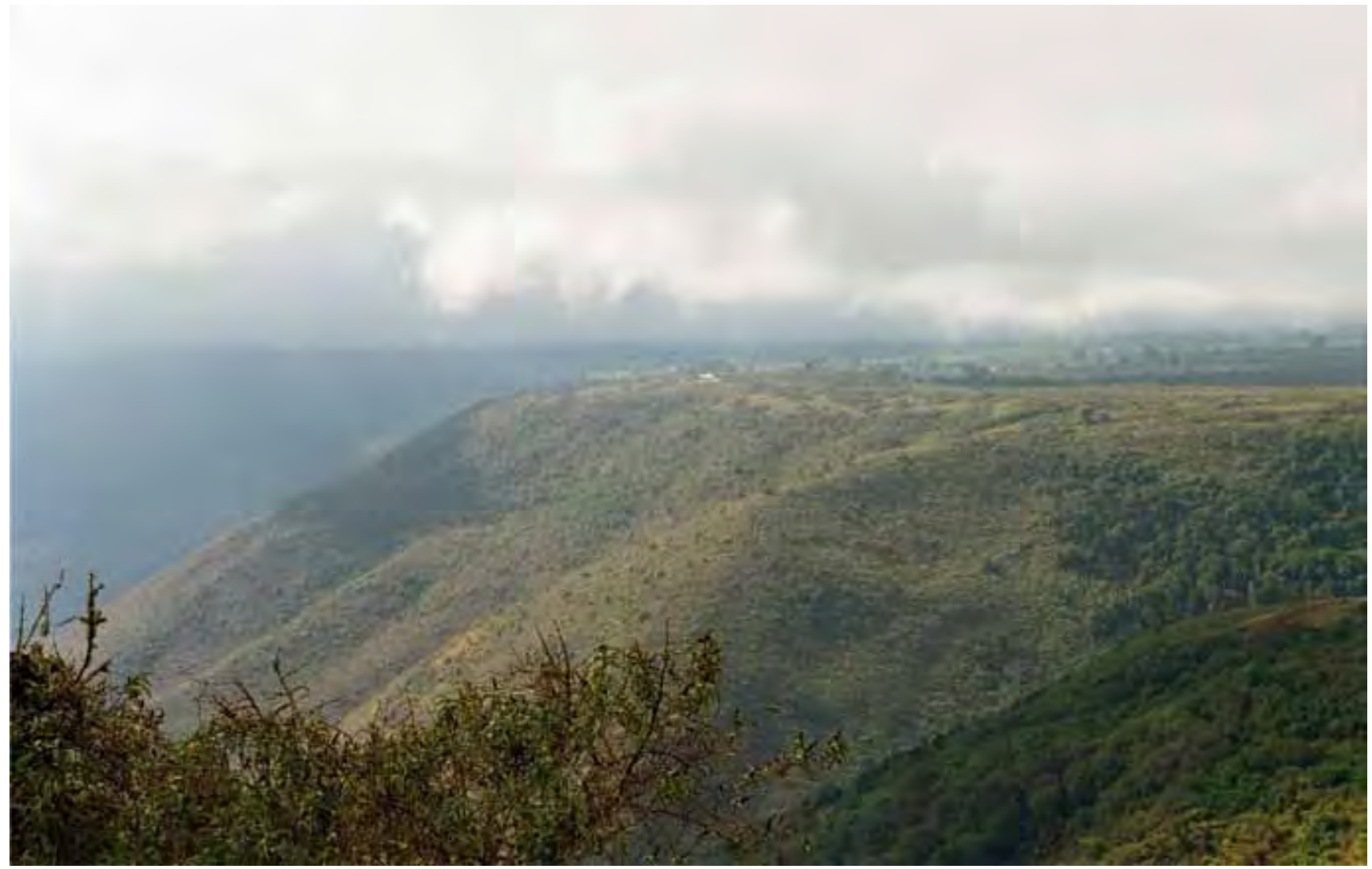

Fig. 10. Cloudy weather on the Crater rim, phot. J. Żaba • Częste, znaczne zachmurzenie na obrzeżach krateru, fot. J. Żaba 
The Crater floor is covered mainly by open short grass plains (Figs. 11, 13) with occasional umbrella acacia Acacia tortilis and Commiphora africana trees, and it becomes almost a desert during periods of severe drought. Among grasses occurring in this area, Hyparrenia ruta, Aristida kenyensis, Pennisetum mezianum, rhoded grass Chloris gayana, Themeda triandra, knot grass Cynodon dactilon, Digitaria macroblephara, or Andropogon grass dominate (Tombazzi 2003). On the plains, there are also fresh and brackish water lakes, marshes, swamps and two patches of acacia woodland: the Lerai Forest (Figs. 14, 15), with codominant yellow fever tree Acacia xanthophloea and African quinine Rauvolfia caffra, as well as the Laiyanai Forest with pillar wood Cassipourea malosana, peacock flower Albizzia gummifera, and red thorn Acacia lahai (Figs. 5, 11; UNESCO/IUCN 2008).

A population of some 25,000 large animals, largely ungulates, alongside the highest density of mammalian predators in Africa, live in the Ngorongoro Crater. Among them, the most commonly observed species are: wildebeest, also known as gnu Connochaetes taurinus (in 1994 its population in the Crater was estimated to about 7,000 individuals), zebra Equus burchelli (population of about 4,000 in 1994; Figs 16, 17), eland Taurotragus oryl, and Grant's and Thomson's gazelles Gazella granti and Gazella thomsoni (population of about 3,000 in 1994; UNESCO/IUCN 2008).

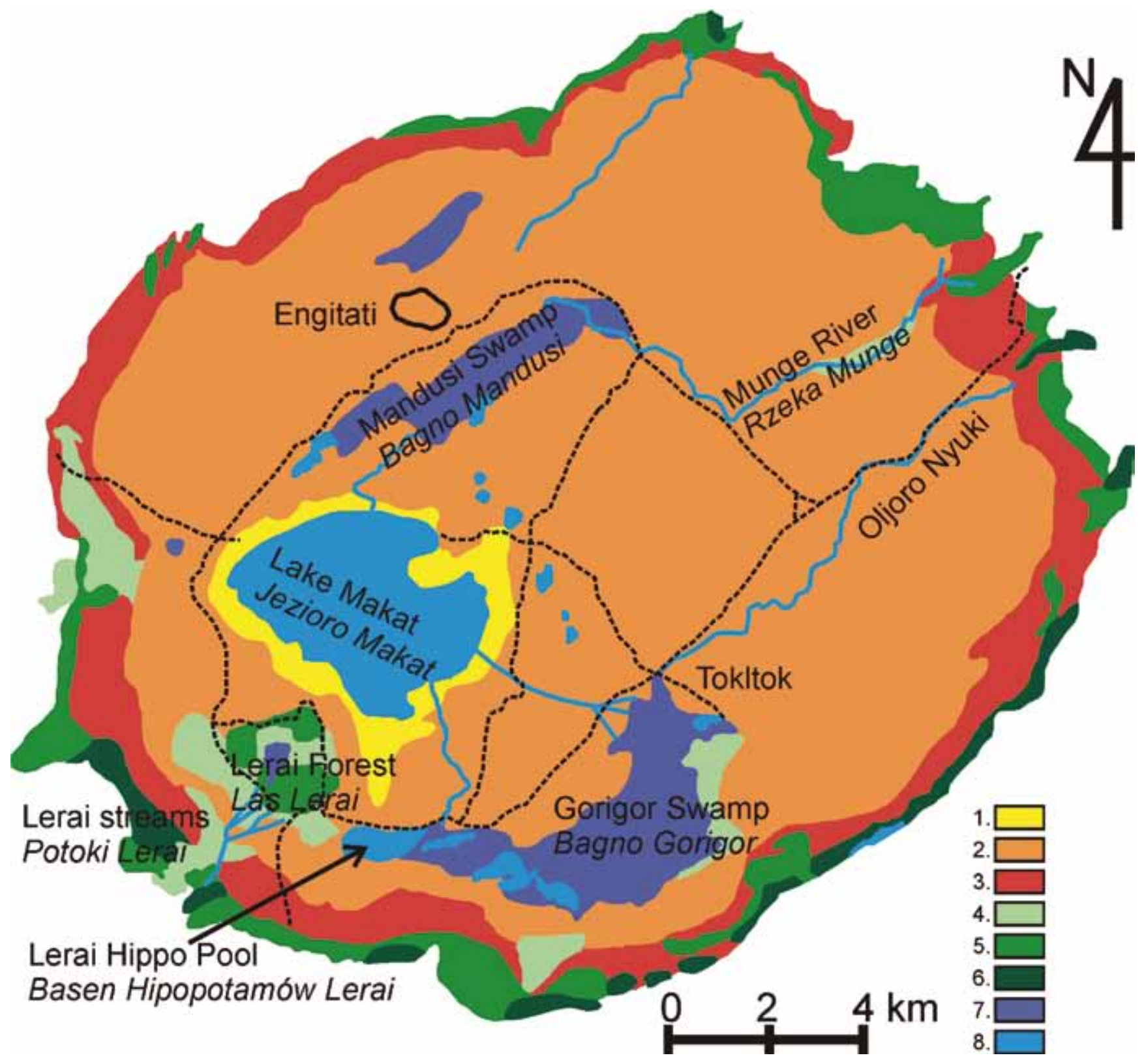

Fig. 11. Flora of the Ngorongoro Crater (according to Chuwa 2000, vide Estes et al. 2006, modified and supplemented).

1 - short grassland, 2 - medium grassland, 3 - bushland, 4 - low woodland, 5 - high woodland, 6 - moist evergreen forest, 7 - reed swamp, 8 - water/dried lakes. • Flora krateru Ngorongoro (według Chuwa 2000, vide Estes et al. 2006, zmienione i uzupełnione). 1 - niska łąka, 2 - średnia łąska, 3 - busz, 4 - niski teren leśny, 5 - wysoki teren leśny, 6 - wilgotny, wiecznie zielony las równikowy, 7 - bagno szuwarowe, 8 - woda/suche jeziora 
Tab. 1. Chosen species of plants from the Ngorongoro Crater (according to Tombazzi 2003, supplemented) • Wybrane gatunki roślin krateru Ngorongoro (według Tombazzi 2003, uzupełnione)

\begin{tabular}{|c|c|c|c|c|c|}
\hline $\begin{array}{l}\mathrm{No} \\
\mathrm{Nr}\end{array}$ & $\begin{array}{l}\text { English } \\
\text { (angielski) }\end{array}$ & $\begin{array}{l}\text { Latin } \\
\text { (łacina) }\end{array}$ & $\begin{array}{l}\text { Polish } \\
\text { (polski) }\end{array}$ & $\begin{array}{c}\text { Maa language } \\
\text { (język Maa) }\end{array}$ & $\begin{array}{c}\text { Height }[\mathrm{m}] \\
\text { wysokość }[\mathrm{m}]\end{array}$ \\
\hline 1 & Flat-top Acacia & Acacia abyssinica & Akacja abisyńska & Oltepesi & 9 \\
\hline 2 & Wait-a-bit Thorn & Acacia brevispica & - & Eiti & - \\
\hline 3 & $\begin{array}{l}\text { Whistling Thorn or Ant-galled } \\
\text { Acacia }\end{array}$ & $\begin{array}{c}\text { Acacia } \\
\text { drepanolobium }\end{array}$ & „Mrówcze drzewo" & Olwai & 2 \\
\hline 4 & Red Thorn & Acacia lahai & - & Ormelelek & 10 \\
\hline 5 & Fever Tree or Yellow Barked Acacia & Acacia xanthophloea & - & Oltepesi & 18 \\
\hline 6 & Peacock Flower Tree & Albizia gummifera & - & - & 20 \\
\hline 7 & Pillarwood & $\begin{array}{l}\text { Cassipourea } \\
\text { malosana }\end{array}$ & - & Osonjoi & 30 \\
\hline 8 & Wild Mango & Cordyla africana & - & - & 8 \\
\hline 9 & Crotalaria & Crotalaria agatiflora & Kanarkowiec & Alairayray & 3 \\
\hline 10 & Broad-Leaved Croton & Croton macrostachyus & - & - & 15 \\
\hline 11 & Croton Tree & Croton megalocarpus & Croton Wielki & - & 25 \\
\hline 12 & Candelabra Tree & $\begin{array}{l}\text { Euphorbia } \\
\text { candelabrum }\end{array}$ & $\begin{array}{l}\text { Wilczomlecz } \\
\text { kandelabrowy }\end{array}$ & Orpopong'i & 12 \\
\hline 13 & - & Ficus thonningii & Figowiec & Oreteti & 20 \\
\hline 14 & Nuxia Congesta & Lachnopylis congesta & - & Olopironi & 12 \\
\hline 15 & Lion's Paw & Leonotis nepetifolia & $\begin{array}{l}\text { Ucho Lwa, Klip } \\
\text { Dagga }\end{array}$ & Olbibiai & 3 \\
\hline 16 & Aerial "Barbed" Lichens & Usnea & Brodaczka & - & - \\
\hline 17 & - & Vernonia auriculifera & - & Osumbat & - \\
\hline
\end{tabular}

Tab. 2. Chosen animal species from the Ngorongoro Crater and their population in 2006 (according to www.ngorongorocrater. org, supplemented) • Wybrane gatunki zwierząt żyjących w kraterze Ngornogoro wraz z ich liczebnością w roku 2006 (według www.ngorongorocrater.org, uzupełnione) 


\begin{tabular}{|c|c|c|c|c|c|}
\hline \multirow{2}{*}{$\begin{array}{l}\mathrm{No} \\
\mathrm{Nr}\end{array}$} & \multirow{2}{*}{$\begin{array}{l}\text { English } \\
\text { (angielski) }\end{array}$} & \multirow{2}{*}{$\begin{array}{l}\text { Latin } \\
\text { (łacina) }\end{array}$} & \multirow{2}{*}{$\begin{array}{l}\text { Polish } \\
\text { (polski) }\end{array}$} & \multicolumn{2}{|c|}{ Population (Populacja) } \\
\hline & & & & $\begin{array}{c}\text { Dry season } \\
\text { (Sezon suchy) }\end{array}$ & $\begin{array}{c}\text { Rainy season } \\
\text { (Sezon deszczowy) }\end{array}$ \\
\hline 1 & Cheetah & Acinonyx jubatus & Gepard & 1 & 9 \\
\hline 2 & Kongoni (hartebeest) & $\begin{array}{l}\text { Alcelaphus } \\
\text { buselaphus }\end{array}$ & $\begin{array}{c}\text { Bawolec, } \\
\text { antylopa krowia }\end{array}$ & 112 & - \\
\hline 3 & Kori Bustard & Ardeotis kori & Drop olbrzymi & 31 & 2 \\
\hline 4 & Crown Crane & Balearicinae & $\begin{array}{c}\text { Koronnik, } \\
\text { żuraw } \\
\text { koroniasty }\end{array}$ & 82 & 10 \\
\hline 5 & Side-striped Jackal & Canis adustus & $\begin{array}{c}\text { Szakal } \\
\text { pręgowany }\end{array}$ & - & 18 \\
\hline 6 & Golden Backed Jackal & Canis aureus & $\begin{array}{c}\text { Szakal złocisty, } \\
\text { pospolity, } \\
\text { azjatycki }\end{array}$ & 9 & 20 \\
\hline 7 & $\begin{array}{c}\text { Silver Backed Jackal (Black-backed } \\
\text { Jackal, Red Jackal) }\end{array}$ & Canis mesomelas & $\begin{array}{c}\text { Szakal } \\
\text { czaprakowy }\end{array}$ & 9 & 30 \\
\hline 8 & Vervet Monkey & $\begin{array}{l}\text { Chlorocebus } \\
\text { pygerythrus } \\
\text { (Cercopithecus } \\
\text { pygerythrus) }\end{array}$ & $\begin{array}{l}\text { Koczkodan } \\
\text { tumbili, } \\
\text { werweta }\end{array}$ & - & 8 \\
\hline 9 & Wildebeest (gnu) & Connochaetes & Gnu & 3385 & 3 \\
\hline 10 & Black rhinoceros & Diceros bicornis & $\begin{array}{c}\text { Nosorożec } \\
\text { czarny }\end{array}$ & 13 & 15 \\
\hline 11 & Zebra & Equus & Zebra & 3484 & 25 \\
\hline 12 & Thomson Gazelle & Eudorcas thomsonii & $\begin{array}{c}\text { Gazela } \\
\text { Thompsona } \\
\text { (Tomi) }\end{array}$ & 1549 & 12 \\
\hline 13 & Hippo & $\begin{array}{l}\text { Hippopotamus } \\
\text { amphibius }\end{array}$ & $\begin{array}{l}\text { Hipopotam } \\
\text { nilowy }\end{array}$ & 93 & 20 \\
\hline 14 & Hyena & Hyaeninae & Hiena & 47 & 12 \\
\hline 15 & Waterbuck & Kobus ellipsiprymnus & Kob śniady & 23 & 3 \\
\hline 16 & Serval Cat & Leptailurus serval & Serwal & - & - \\
\hline 17 & African Bush Elephant & Loxodonta africana & Słoń afrykański & 333 & - \\
\hline 18 & Dik-dik & Madoqua saltiana & Dikdik & - & - \\
\hline 19 & Grant Gazelle & $\begin{array}{l}\text { Nanger granti } \\
\text { (Gazella granti) }\end{array}$ & Gazela Granta & 764 & - \\
\hline 20 & Bat Eared Fox & Otocyon megalotis & Otocjon & - & 15 \\
\hline 21 & Lion & Panthera leo & Lew & 49 & 13 \\
\hline 22 & Leopard & Panthera pardus & Lampart & - & - \\
\hline 23 & Baboon & Papio & Pawian & - & 31 \\
\hline 24 & Warthog (Common warthdog) & $\begin{array}{l}\text { Phacochoerus } \\
\text { africanus }\end{array}$ & Guziec & 63 & 92 \\
\hline 25 & Reedbuck & Redunca & Redunca & - & - \\
\hline 26 & Secretary Bird & $\begin{array}{c}\text { Sagittarius } \\
\text { serpentarius }\end{array}$ & Sekretarz & 8 & 2 \\
\hline 27 & Ostrich & Struthio camelus & Struś & 68 & 114 \\
\hline 28 & $\begin{array}{l}\text { African buffalo, affalo or Cape } \\
\text { buffalo }\end{array}$ & Syncerus caffer & $\begin{array}{c}\text { Bawół } \\
\text { afrykański, } \\
\text { kafryjski, } \\
\text { przylądkowy }\end{array}$ & 2045 & 3106 \\
\hline 29 & Eland & Taurotragus oryx & Eland & 25 & 59 \\
\hline 30 & Bushbuck & Tragelaphus scriptus & Buszbok & - & - \\
\hline
\end{tabular}




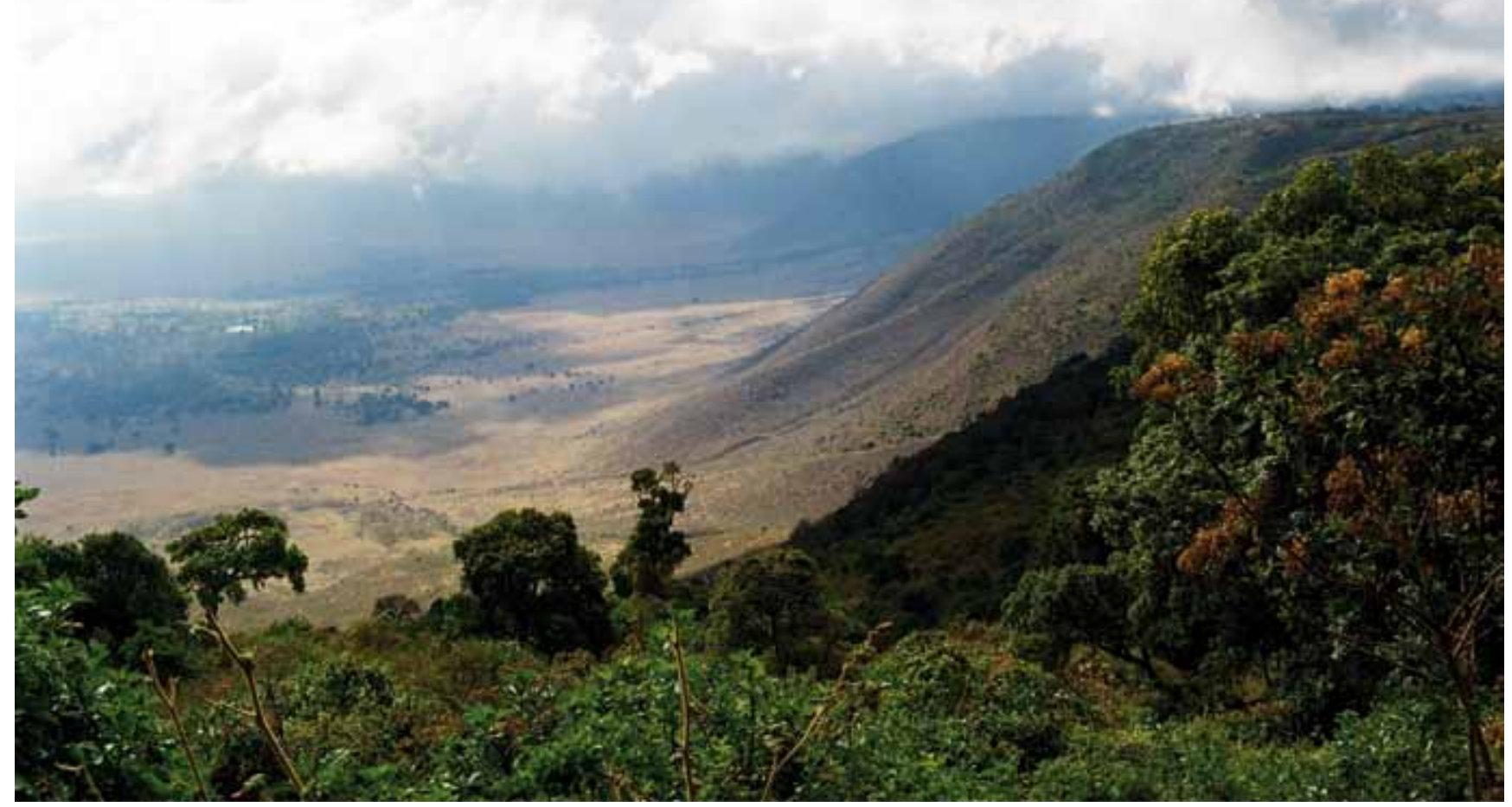

Fig. 12. The remains of the evergreen montane forests on the steep slopes of the Ngorongoro Crater, phot. J. Żaba • Pozostałości wiecznie zielonych lasów górskich na stromych stokach krateru Ngorongoro, fot. J. Żaba

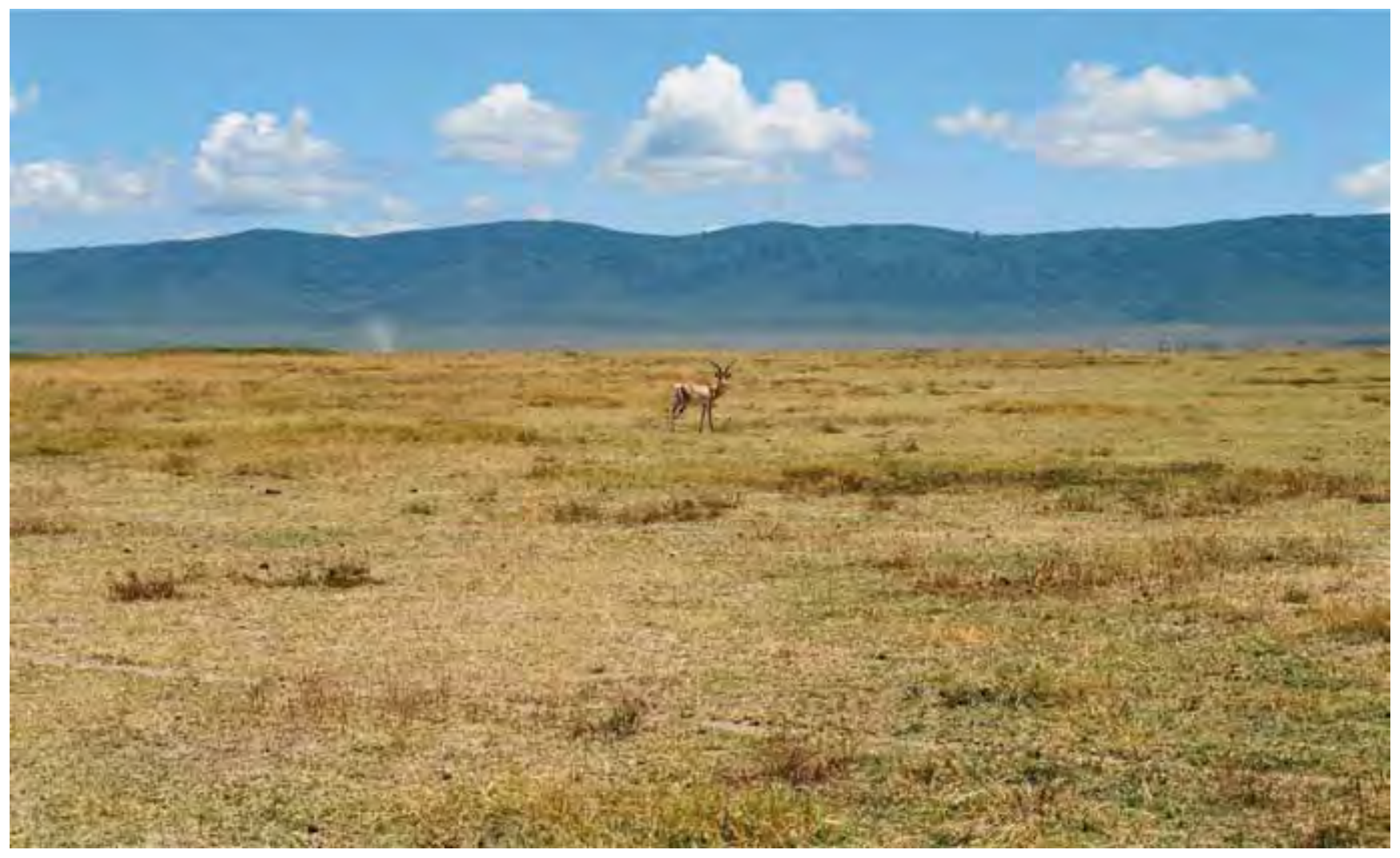

Fig. 13. Open grasslands on the mainly flat floor of the Ngorognoro Crater constitute the perfect living conditions for the ungulates, phot. J. Żaba • Roślinność trawiasta porastająca głównie płaskie dno krateru Ngorongoro, stanowiąca idealne warunki bytowe dla zwierząt kopytnych, fot. J. Żaba 


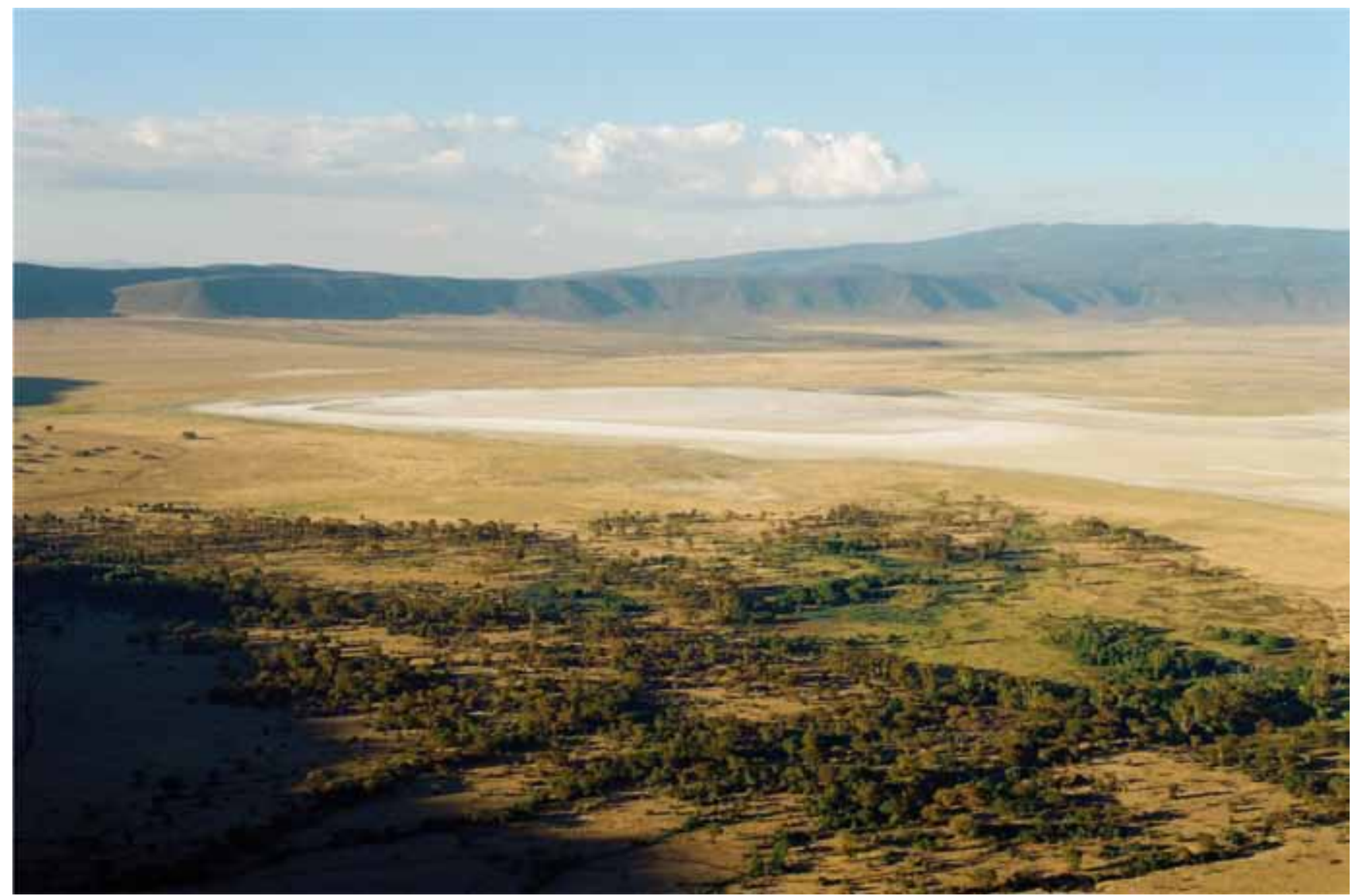

Fig. 14. View on the Lerai Forest and Lake Makat from the Crater rim, phot. J. Żaba $\bullet$ Widok na Las Lerai i Jezioro Makat $\mathrm{z}$ obrzeży Krateru, fot. J. Żaba

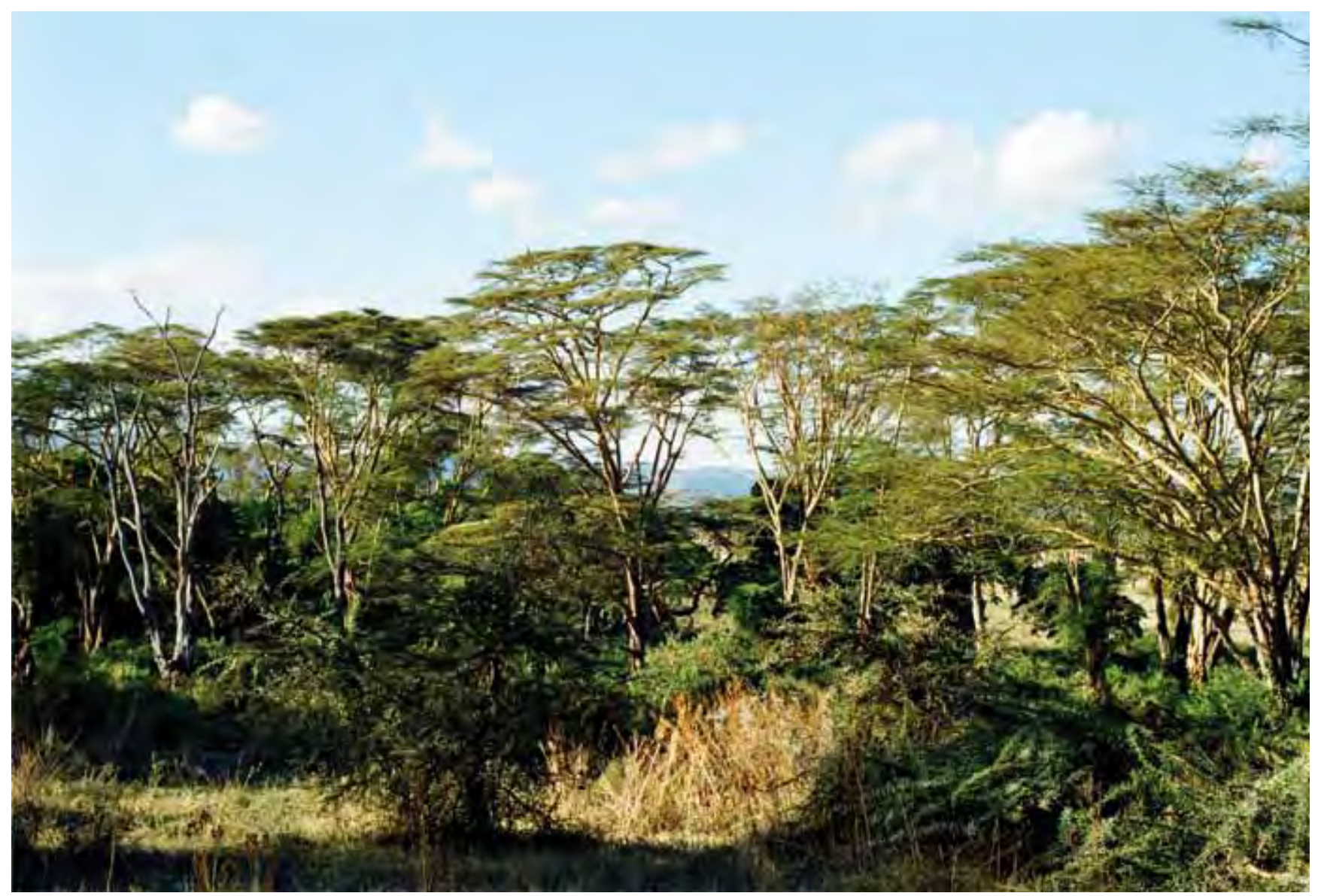

Fig. 15. The Lerai Forest, phot. J. Żaba • Las Lerai, fot. J. Żaba 


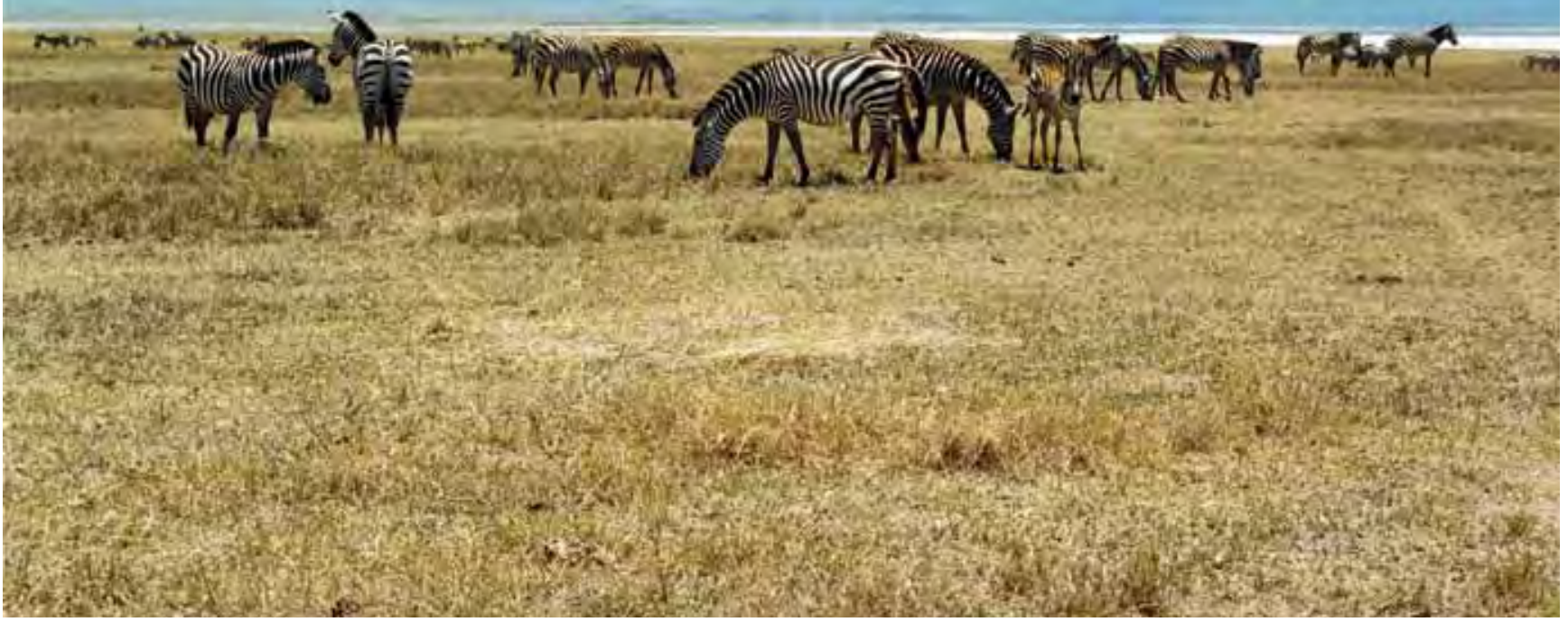

Fig. 16. Zebras on the short-grassland of the Ngorongoro Crater floor, phot. J. Żaba • Stado zebr na dnie krateru Ngorongoro, fot. J. Żaba

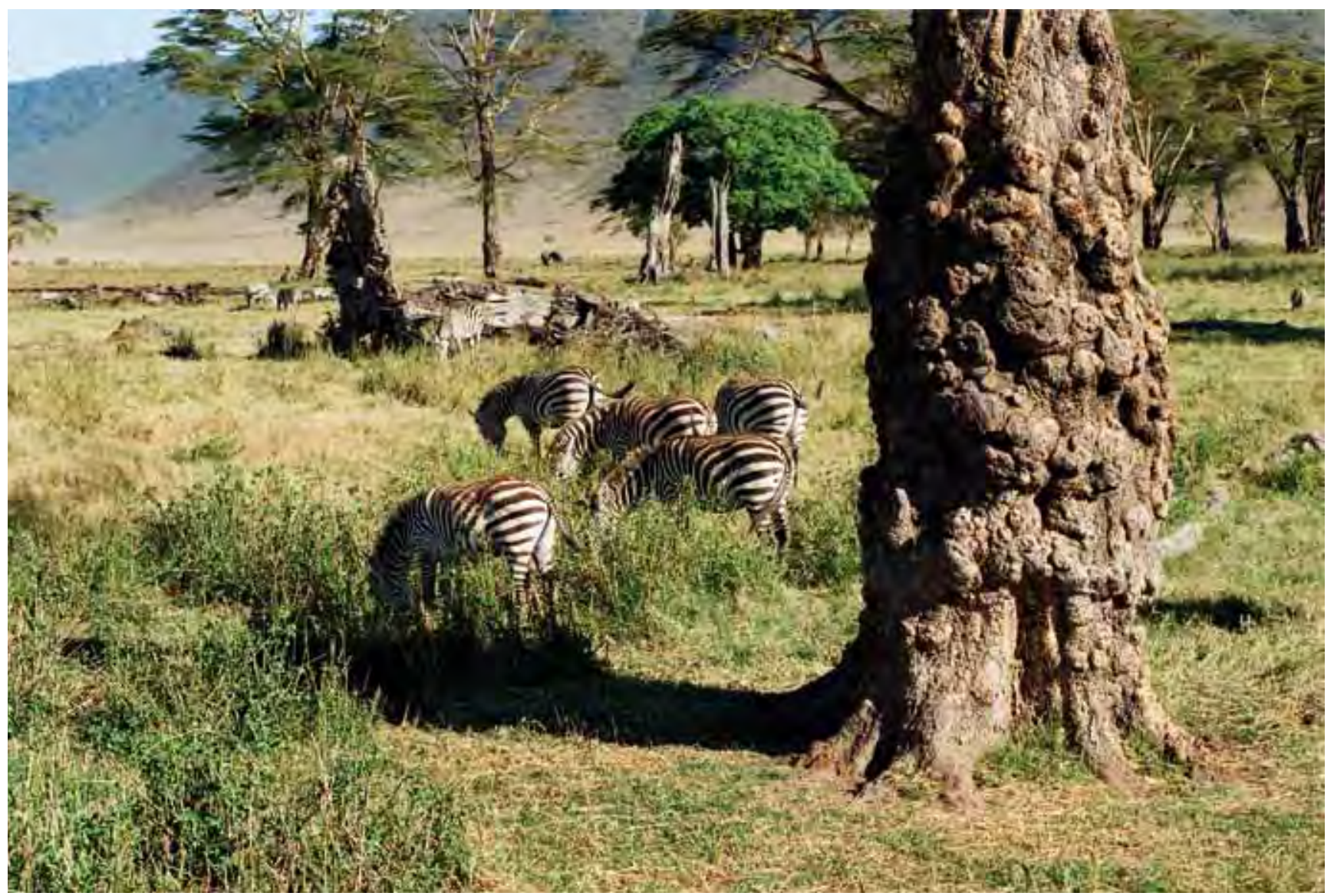

Fig. 17. Zebras in the shadow of the acacia trees, phot. J. Żaba • Zebry pasące się w cieniu akacji, fot. J. Żaba 
Also very common in the Crater are: African buffalo, affalo or cape buffalo Syncerus caffer (Fig. 18), kongoni, hartebeest Alcelaphus buselaphus, as well as warthog, also known as common warthdog Phacochoerus africanus. Populations of some of them reach about 5,000 individuals, especially in the dry season (Tab. 2). Due to very extensive grasslands and bush, relatively untouched by cultivation, constant access to clean, fresh water in the form of springs, perennial and seasonal rivers as well as small freshwater lakes, these large ungulate animals have almost ideal living conditions in the Ngorongoro Crater (Fig. 11).

The occurrence of wetlands (marshes and swamps) and forests provides an excellent environment within the Ngorongoro Crater to life for such species, as: hippo Hippopotamus amphibius (Fig. 19), commonly observed in the Hippo Pool basin, as well as reedbuck Redunca, bushbuck Tragelaphus scriptus, baboon Papio, African bush elephant Loxodonta africana (Fig. 20), or vervet monkey Chlorocebus pygerythrus, Cercopithecus pygerythrus (http://www.ngorongorocrater.org/welcome.html). Waterbuck Kobus ellipsiprymnus occurs mainly in the vicinity of the Lerai Forest (Fig. 11). About 400-600 $\mathrm{m}$ above the depression, on the Crater rim, there occur: elephant Loxodonta africana, numbering 42 in 1987 but 29 in 1992 (Said et al. 1995), mountain reedbuck Redunca fulvorufula, hartebeest Alcelaphus buselaphus, and buffalo Syncerus caffer (4,000 in 1994) (Estes, Small 1981; UNESCO/IUCN 2008).

The Ngorongoro Crater is not just a paradise with ungulates living free and wild. It is also inhabited by large, fast and vicious predators. In fact, this specific location is characterized by the highest density of mammalian predators in Africa. Among them, the most common in the Crater are species belonging to the biological family Felidae (cats). Being in the Crater it is very easy to observe the second largest living cat on Earth, the lion Panthera leo. In the Ngorongoro Crater its population is the densest known lion population on Earth. Although actually its population is not so large, numbering only 62 in 2001, though these suffer from inbreeding (Fig. 21; Kangera 2002). Other predator species living here, in addition to the aforementioned lion, are: leopard Panthera pardus inhabiting the Crater rim, serval cat Leptailurus serval, and much rarer cheetah Acinonyx jubatus. According to the UNESCO report (2008), in recent years in the forests of the Ngorongoro Crater the presence of African golden cat Profelis aurata was recorded. Furthermore, there also occur medium-sized herd of hyenas Hyaeninae (Fig. 22), mostly spotted hyena, also known as laughing hyena Crocuta crocuta, as well as various species of jackals (Tab. 2): silver backed jackal Canis mesomelas, golden backed jackal Canis aureus, and side-striped jackal Canis adustus. Wild dog Lycaon pictus, also known as African wild dog, African hunting dog, painted wolf, cape hunting dog, painted dog, painted hunting dog, spotted dog or ornate wolf, has recently disappeared from the Crater. Probably, its population has declined also elsewhere in the Crater Highlands (UNESCO/IUCN 2008).

However, the best known and most endangered species of the Ngorongoro Crater is the black rhino Diceros bicornis.

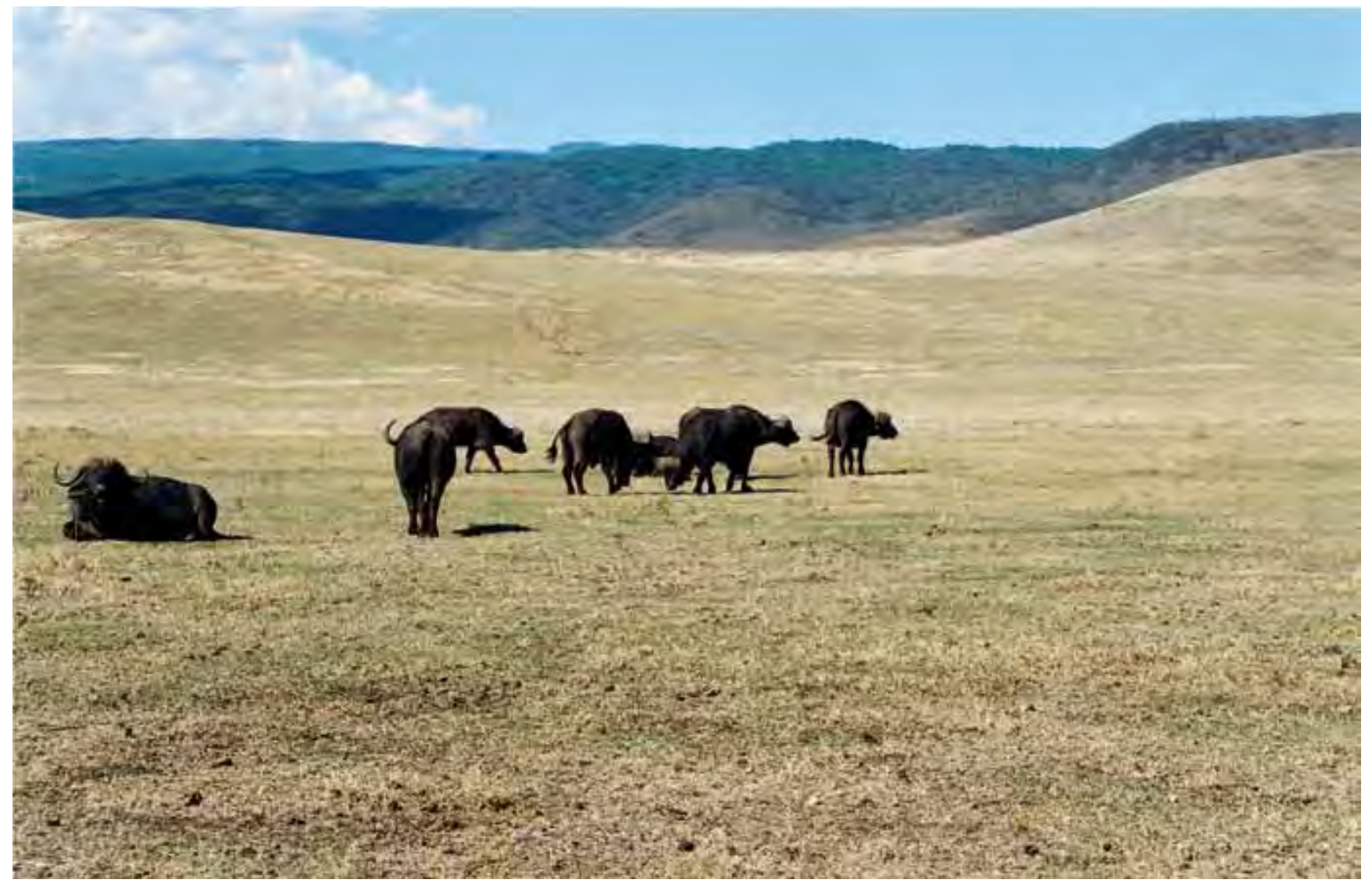

Fig. 18. Highly dangerous to human, not domesticated the African buffalo, phot. J. Żaba • Bardzo niebezpieczny dla człowieka, nieudomowiony bawół afrykański, fot. J. Żaba 


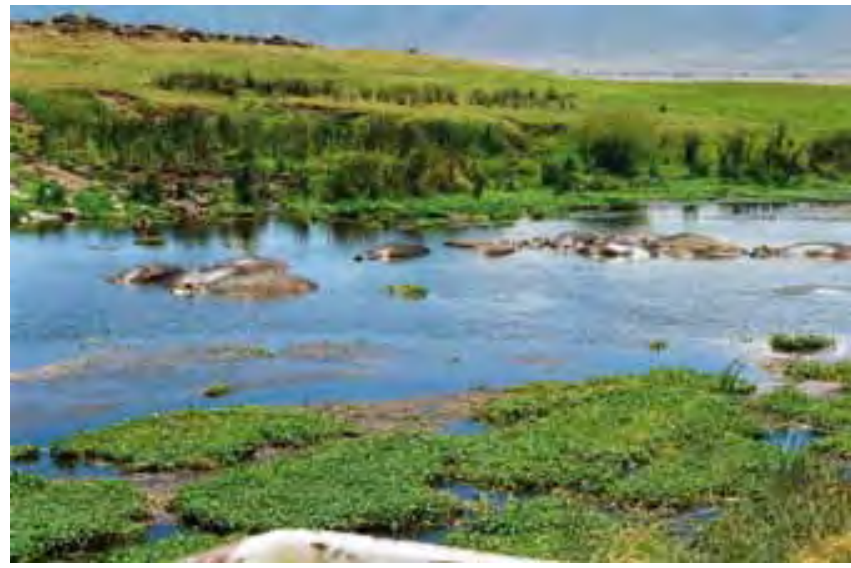

Fig. 19. Hippos in the Hippo Pool Basin, phot. J. Żaba • Hipopotamy z Basenu Hipopotamów, fot. J. Żaba

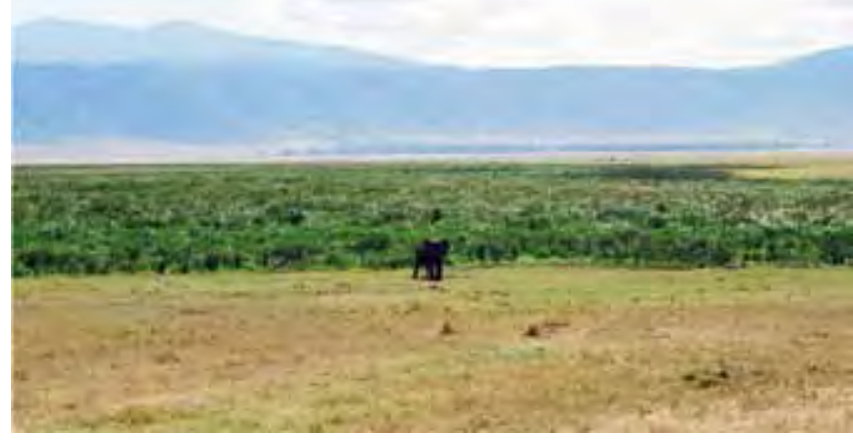

Fig. 20. The biggest of all the three living species of elephant - the African bush elephant, phot. J. Żaba • Słoń afrykański - największy spośród trzech żyjących gatunków słoniowatych, fot. J. Żaba

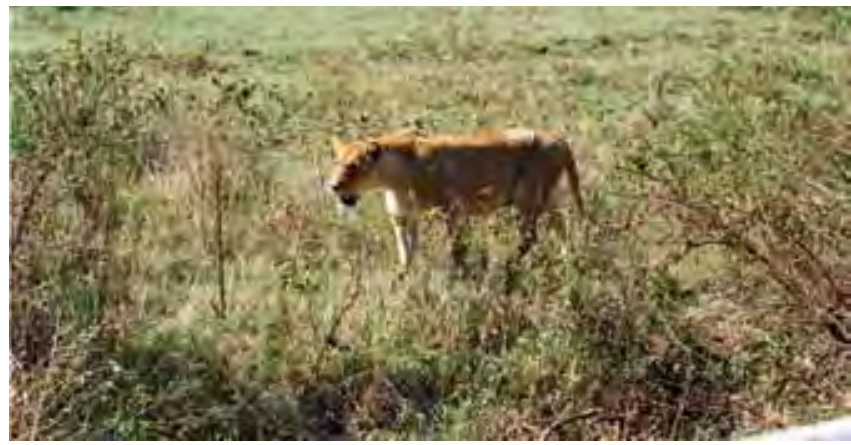

Fig. 21. Lion - the largest predator of the Ngorongoro Crater, phot. J. Żaba • Lew - największy drapieżnik krateru Ngorongoro, fot. J. Żaba

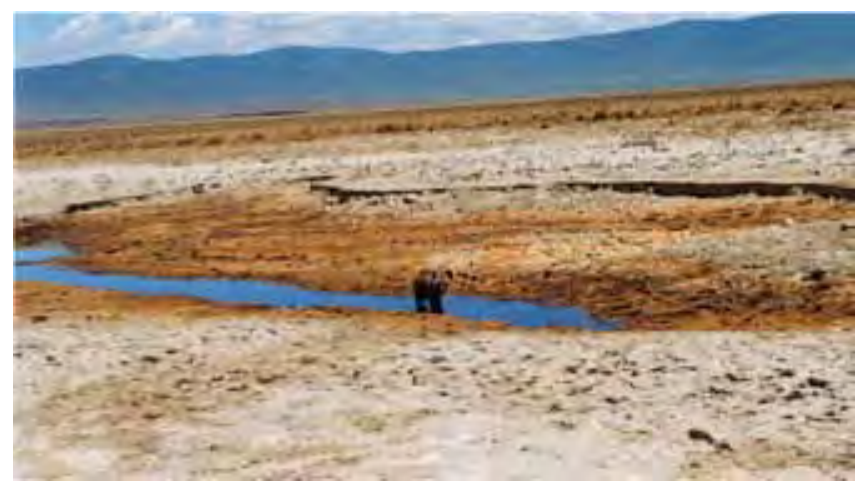

Fig. 22. Lonely hyena wandering through the floor of the Ngorongoro Crater, phot. J. Żaba • Samotna hiena przemierzająca dno krateru Ngorongoro, fot. J. Żaba
It is listed on the Red List of Threatened Species prepared by the IUCN (International Union for Conservation of Nature) as a critically endangered species (http://www.iucnredlist. org/). Despite all the protective activities, its population declined significantly from about 108 in 1964-66 to over a dozen (between 11 and 14) in 1995 (Moehlman et al. 1996). Nowadays, their situation is beginning to stabilize, they are relatively safe, and their population in the Crater again exceeds 20 individuals (http://www.ngorongorocrater.org/welcome. html).

Over 500 species of birds are recorded within the Ngorongoro Crater and adjacent areas, which lies within one of the world's Endemic Bird Areas (Fishpool, Evans, eds. 2001). The most numerous in the Ngorongoro Crater is the population of flamingos (Phoenicopterus) that inhabit the Lake Makat (Fig. 23), mostly of two species: greater flamingo Phoenicopterus ruber and lesser flamingo Phoenicopterus minor. Among the other larger birds present here, the most common species are: ostrich Struthio camelus (Fig. 24) and white pelican Pelicanus onocrotalus. The wetlands of the Gorigor Swamp or Mandusi Swamp, where over a million birds foregather, are visited by squacco heron Ardeola ralloides, African spoonbill Platalea alba, sacred ibis Threskiornis aethiopicus, speckled duck Anas capensis, whiteheaded duck Oxyura maccoa, kaffir rail Rallus caerulescens, avocet Recurvirostra avosetta, whiskered tern Chlidonius hybridus, and greyheaded gull Larus cirrocephalus (UNESCO/ IUCN 2008).

Among other species of birds living in the Ngorongoro Crater, particularly important and common are: white stork Ciconia ciconia, Abdin's storks Ciconia abdimi, yellowbilled stork Mycteria ibis, lammergeier Gypaetus barbatus, Ruepell's griffon Gyps ruepelli (about 3,000 pairs), Verreaux's eagle Aquila verreauxii, Egyptian vulture Neophron percnopterus, pallid harrier Circus macrourus, lesser falcon Falco naumanni, Taita falcon Falco fasciinucha, kori bustard Choriotis kori, great snipe Gallinaga media, Fischer's lovebird Agapornis fischeri, brownbacked woodpecker Picoides obsoletus crateri, Cape crow Corvus capensis, rosy-breasted longclaw Macronyx ameliae, Karamoja apalis Apalis karamojae, Hunter's cisticola Cisticola hunteri, redthroated tit Parus fringillinus, and Jackson's whydah Euplectes jacksoni. Additionally, the Crater highland forests are inhabited by much smaller but very beautiful birds of sunbirds family Nectariniidae. They are represented by two species: the golden winged sunbird Cinnyris reichenowi syn. Nectarinia reichenowi and eastern double collared sunbird Cinnyris mediocris syn. Nectarinia mediocris. Feeding primarily on nectar, they occupy the same ecological niche as hummingbirds in America (UNESCO/IUCN 2008).

Despite such enormous richness of wildlife in the Ngorongoro Crater and opinion of it as a self-contained ecosystem, some animal species often associated with Africa, can not be observed within this huge depression. Some of them can be seen on the outside slopes of the Crater, or in other parts of the Crater Highlands. Among them, probably the best known are: impala Aepyceros melampus, common tsessebe Damaliscus lunatus, oribi Ourebia ourebi, giraffe Giraffa camelopardalis (Fig. 25), or Nile crocodile Crocodylus niloticus (Estes et al. 2006). 


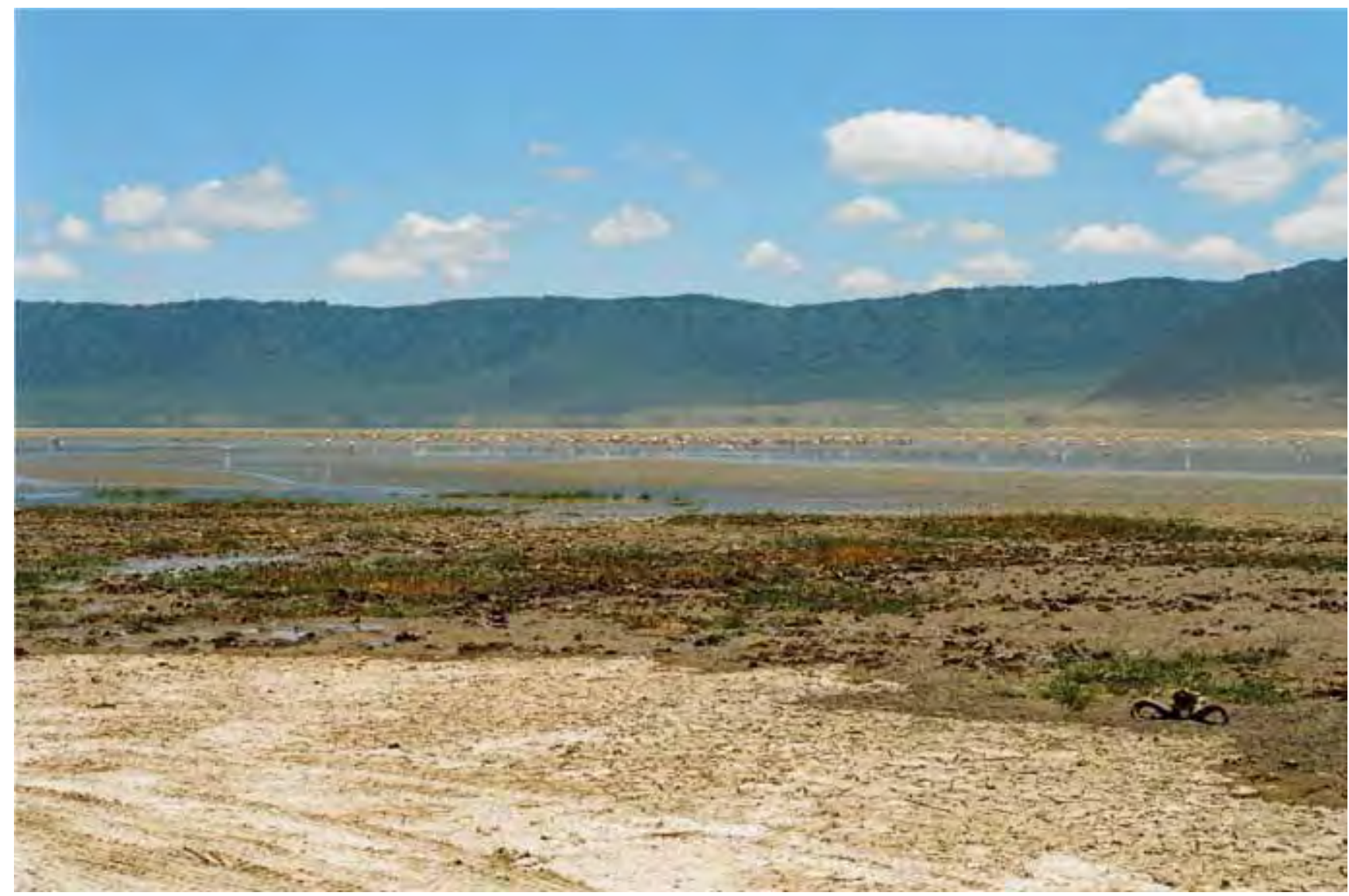

Fig. 23. Flamingos on the Lake Makat, phot. J. Żaba • Flamingi nad jeziorem Makat, fot. J. Żaba

\section{Maasai - the autochthonous population of the Ngorongoro Crater}

Indigenous population of this area is a semi-nomadic Nilotic ethnic group of the Maasai or Masai people. The foundation of their existence is pastoralism and herding cattle (Fig. 26). Due to their semi-nomadic nature, the Maasai have traditionally relied on local, readily available materials and indigenous technology to construct their rather impermanent housing (so-called Inkajijik). These are constructed by women. The Maasai villages are enclosed in a circular fence, built by men, usually of thorn acacia (Fig. 27). At night, all cows, goats and sheep are placed in an enclosure in the centre, safe from wild animals, which have been mentioned in the chapter about wildlife in the Ngorongoro Crater.

The Maasai people speak Maa language (for examples see Tab. 1). They are usually very high, as for African indigenous people. The piercing and stretching of earlobes, with different, sometimes very strange material, is common among the Maasai (Fig. 28). In clothing, they strongly prefer various shades of red (Fig. 29), although black is also common. Head shaving is very common, as the only members of the Maasai community to wear long hair are the warriors. Traditionally, the Maasai diet consisted of meat, milk, and blood from cattle. Especially characteristic for their community is the rite of election of the new ruler of the village. This unique election is in a sort of competition where the winner is the one who jumps the highest (Fig. 30).

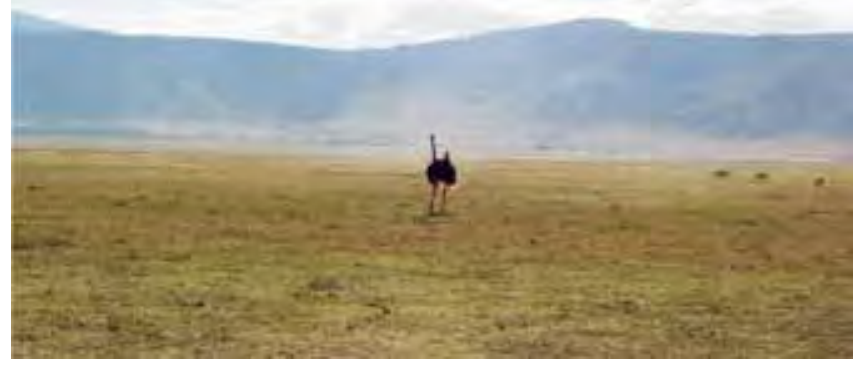

Fig. 24. Ostrich on the floor of the Ngorongoro Crater, phot. J. Żaba - Struś na dnie krateru Ngorongoro, fot. J. Żaba

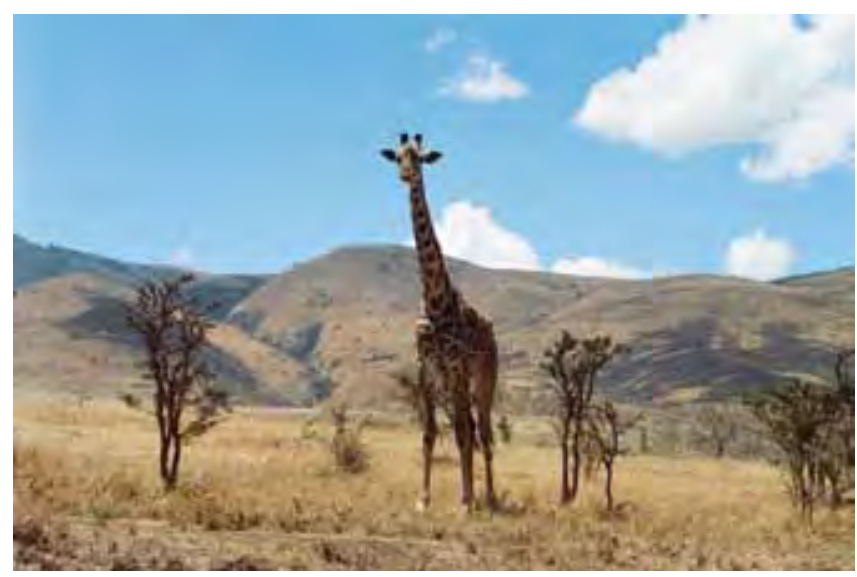

Fig. 25. Giraffe outside the Ngorongoro Crater, phot. J. Żaba • Żyrafa żyjąca poza kraterem Ngorongoro, fot. J. Żaba 


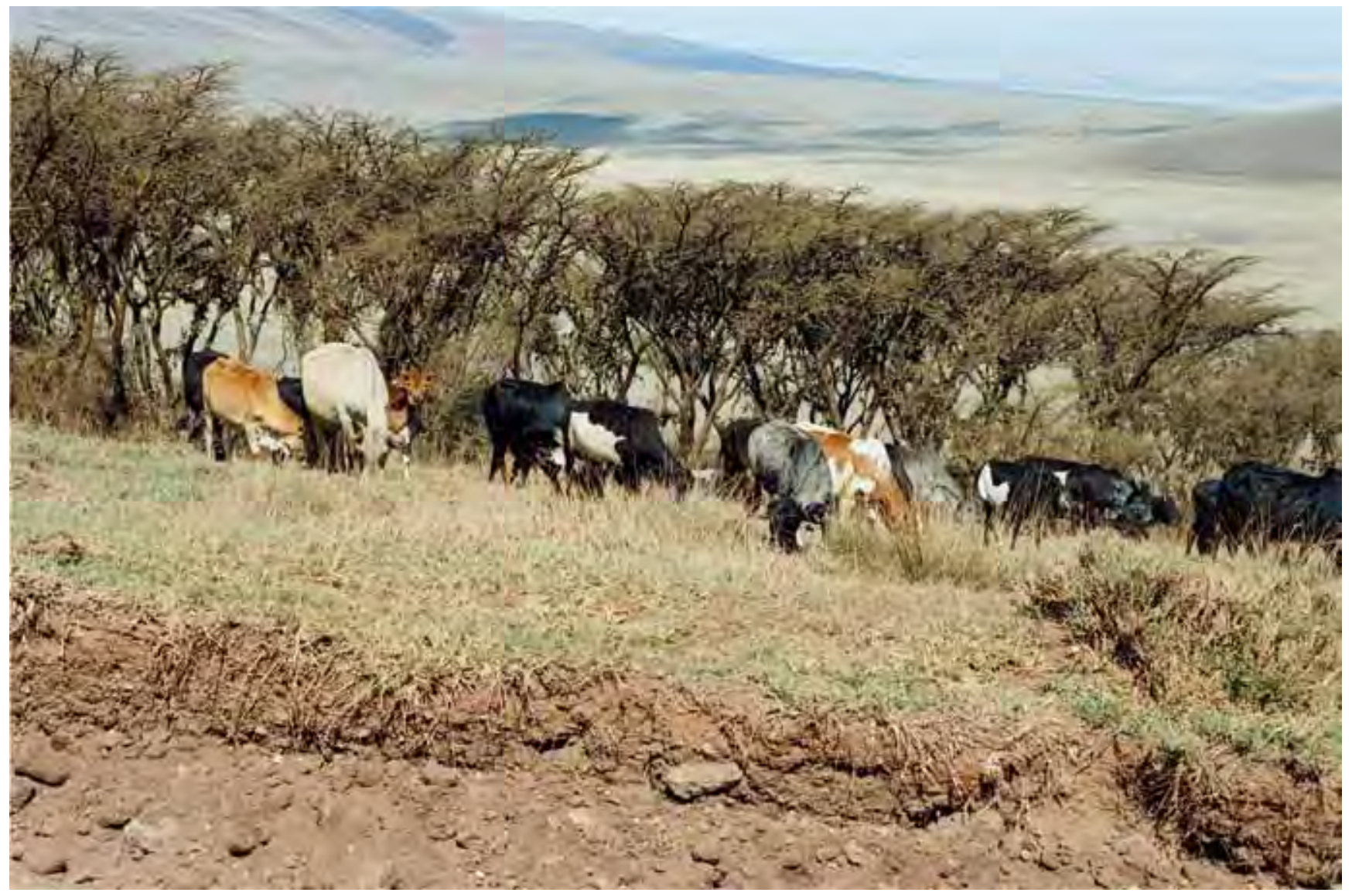

Fig. 26. The Maasai cattle - fundament of their existence, phot. J. Żaba • Bydło masajskie, stanowiące podstawę egzystencji Masajów, fot. J. Żaba

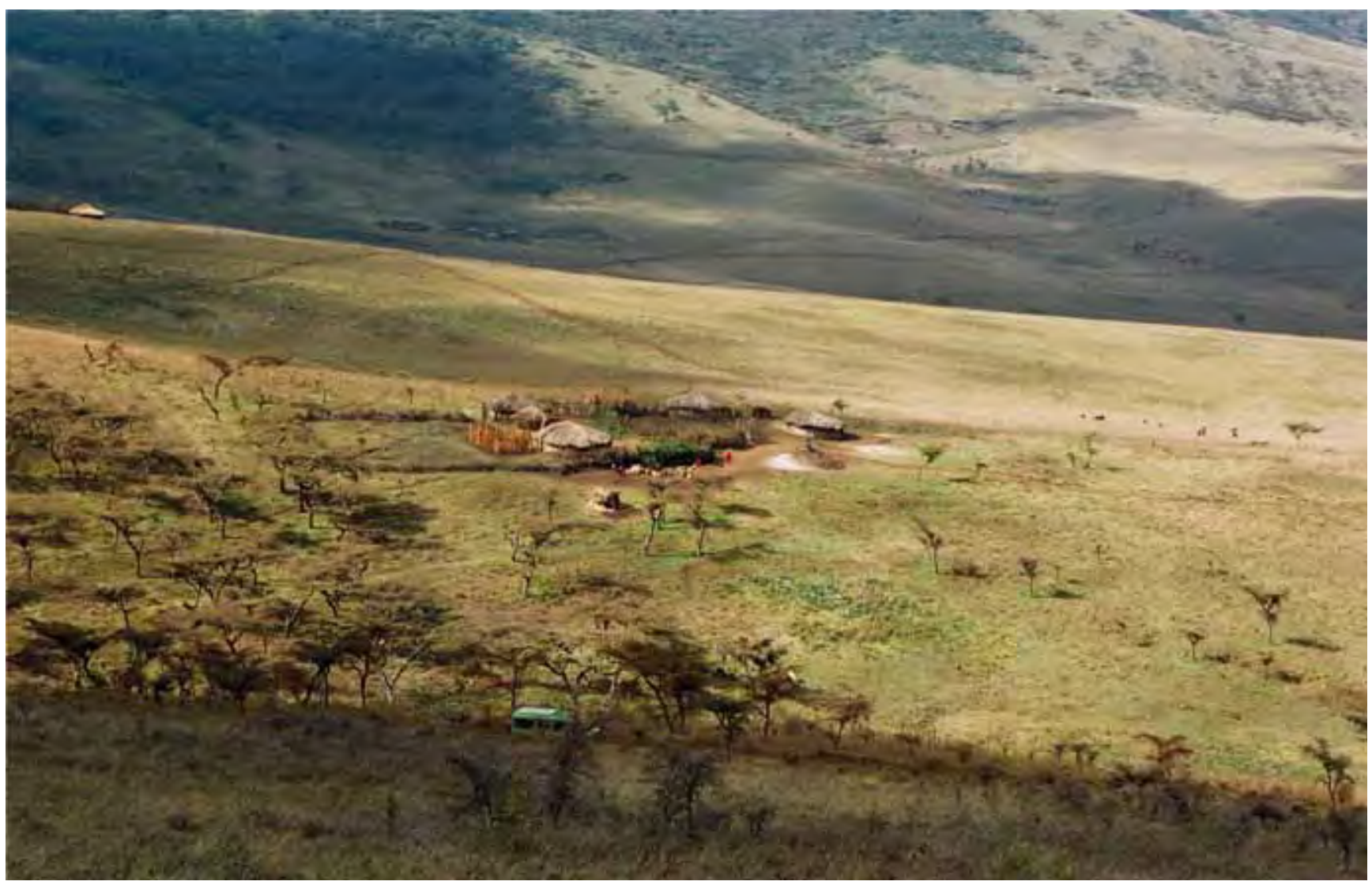

Fig. 27. Typical Maasai village surrounded by the circular acacia fence, phot. J. Żaba • Typowa wioska masajska ogrodzona płotem $\mathrm{z}$ akacji, fot. J. Żaba 
They entered the Ngorongoro Crater around 1840. Since then, their population in this area has been steadily increasing. After the establishment of the Ngorongoro Conservation Area in 1959, the Maasai population living in this area has grown exponentially, reaching in 1966 the number of nearly 9,000 residents in the Crater. It was strictly connected with the proposal aim of the NCA as a multi-use protection area, which supposes to allow and support harmony co-existence of autochthonous people and wildlife. The number of Maasai people reached so high that the population of the area exploded beyond the numbers of cattle able to support it without farming, aggravating tensions with the conservation-oriented administration. That is why in 1974 the Maasai people were evicted from the Crater by the Ngorongoro Conservation Area Authority NCAA. Since that time, there are no permanent inhabitants in the Ngorongoro Crater. Nowadays, the Maasai people resident the areas outside the Crater and other parts of the Crater Highlands. In total, the Maasai population is estimated to less than 900,000, of which more or less one half live in Tanzania and the second half in Kenya. In 1994 in the NCA, the Maasai population was estimated at about 40,000 , with some 300,000 head of livestock, which grazed approximately $70-75 \%$ of the conservation area. In 2006 , resident Maasai were estimated at 60,000 with 300,000 cattle (UNESCO/IUCN 2007). In general, livestock numbers are declining and the Maasai are growing poorer, though some are also beginning to adapt to a sedentary way of life, which may lead to greater participation in the prosperity brought by tourism (UNESCO/IUCN 2008).

\section{Conclusions}

The Ngorongoro Crater is characterized by a large, unique on the global scale, natural and touristic attractions.

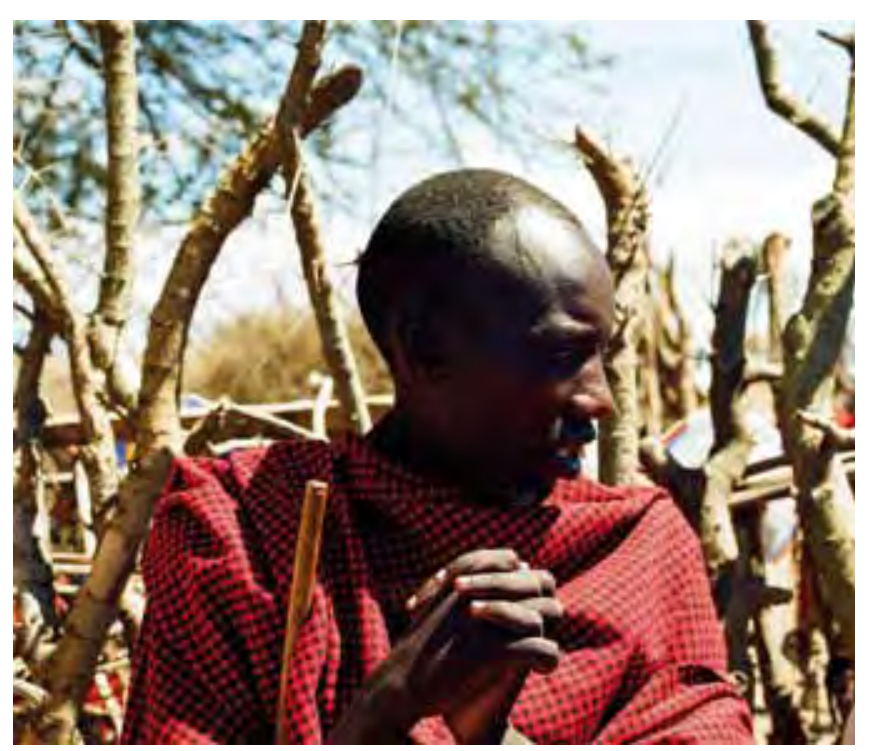

Fig. 28. Stretching of earlobes common for Maasai people, phot. J. Żaba • Powszechne wśród ludności masajskiej rozciąganie małżowin usznych, fot. J. Żaba

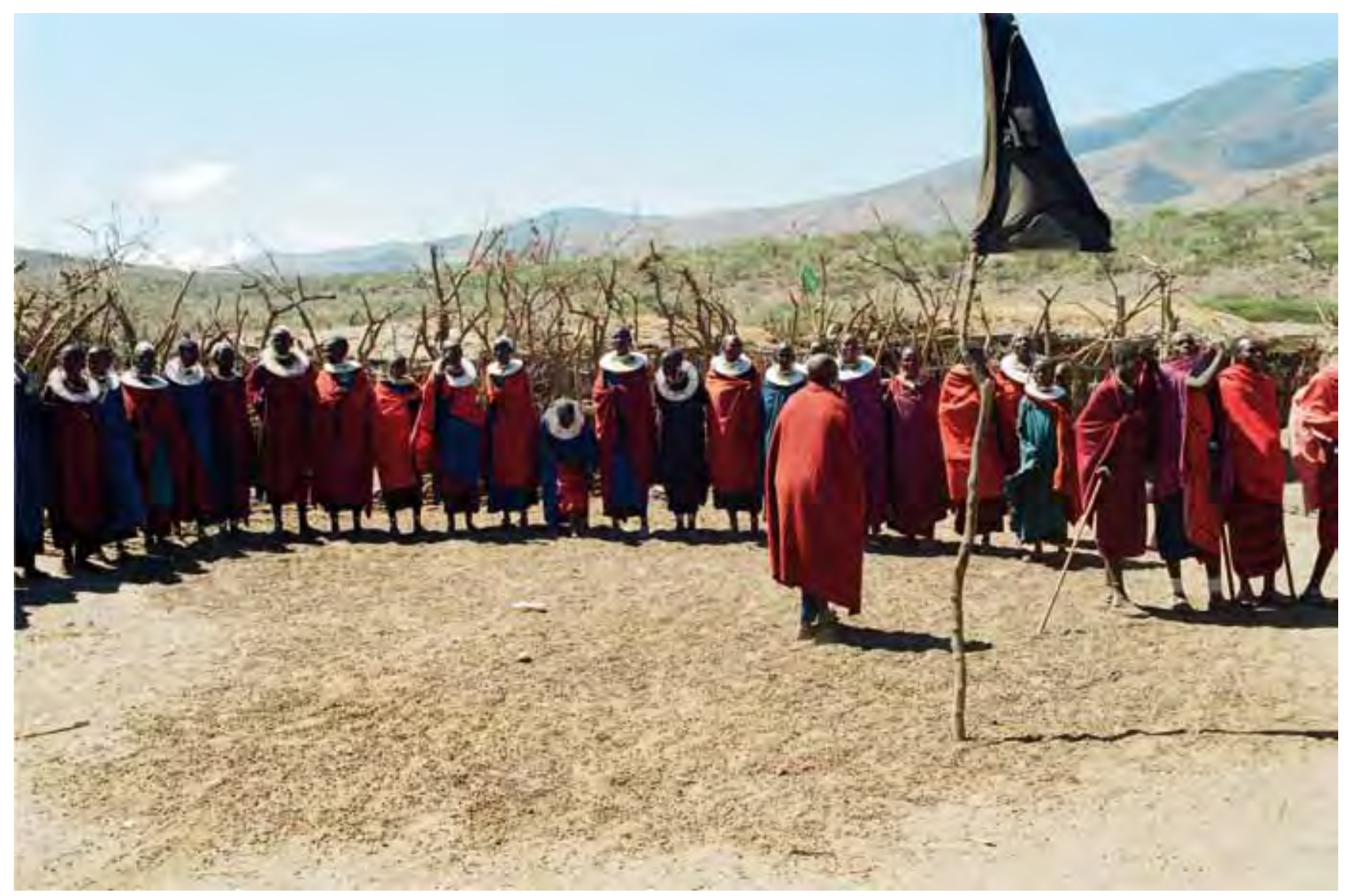

Fig. 29. Representative of the Maasai in their traditional clothes, phot. J. Żaba • Tradycyjne stroje Masajów, fot. J. Żaba 


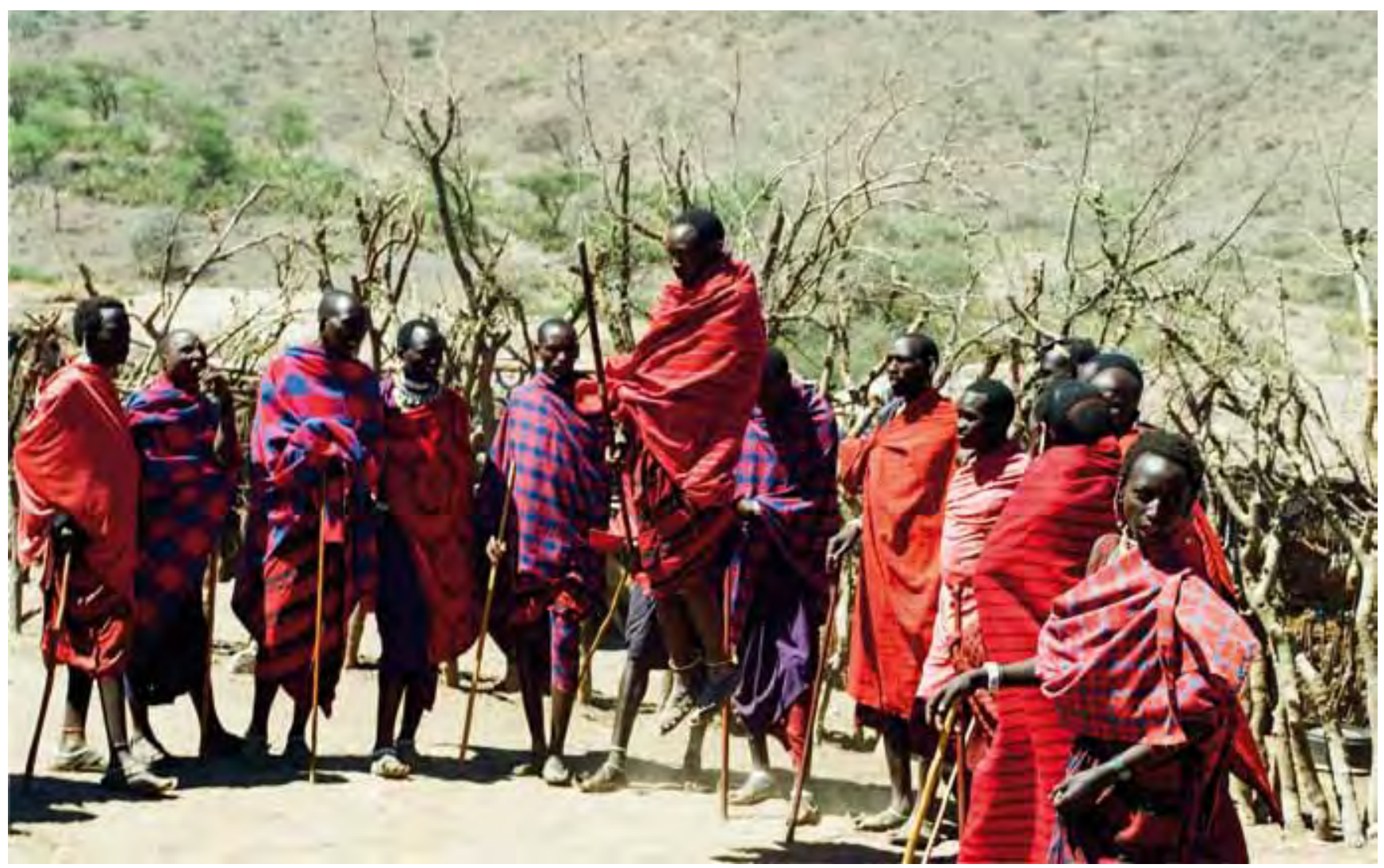

Fig. 30. The election of the new ruler of the village, phot. J. Żaba • Wybory nowego przywódcy wioski, fot. J. Żaba

The majestic scenery together with the richness of living nature, both the flora and fauna, and exotics of the Maasai culture makes the Crater a perfect place for a tourist destination. The diverse and self-sufficient of the Crater wildlife brings to mind "The Lost World" by Sir Arthur Conan Doyle. The absence of some typical African animals, such as giraffes is offset by many rare, indeed endemic animal species, often in danger of extinction, such as black rhino.

The degree of protection and touristic management indicate the unique and exceptional attraction of the Ngorongoro Crater. In 1959, in order to protect its undoubted geotouristic attractions and the other, located in the region, extinct volcanoes, the Ngorongoro Conservation Area was established
(NCA). Due to the richness and diversity of animal and plant world, peculiar example of the geological processes relevant to the development of Earth and outstanding cultural values related to the evolution of humanity, the Ngorongoro Crater was designated as a mixed object on the UNESCO World Cultural and Natural Heritage List. Additionally, the Crater is also included within the Biosphere Reserve created under the UNESCO Man and Biosphere Program, the world's Endemic Bird Area, and the WWF World Eco-regions of freshwater WWF. Furthermore, a short distance from the Ngorongoro Crater another important and well-known geotouristic attraction occurs, the highest mountain in Africa, the Kilimanjaro Volcano (Żaba 2005).

\section{Streszczenie}

\section{Krater Ngorongoro największą atrakcją geoturystyczną ryftu Gregory'ego (północna Tanzania, Afryka) - uwarunkowania geograficzne}

\section{Jerzy Żaba, Krzysztof Gaidzik}

\section{Wstęp}

Krater Ngorongoro to miejsce magiczne przyciągające każdego roku nieprzebrane rzesze turystów. Na terenie tej „naturalnej Arki Afryki” niczym w ogrodzie Edenu żyją w naturalnym środowisku tysiące zwierząt reprezentujące niemal wszystkie gatunki typowe dla Wschodniej Afryki. Krater fascynuje swym wyglądem: potężna kaldera wulkaniczna pełna życia zdaje się przenosić odwiedzających w zamierzchłe czasy (Fig. 1). Skojarzenia z Edenem potęgują doniosłe archeologiczne odkrycia dokonane w pobliżu Krateru. Stwierdzono tam bowiem szczątki naszych przodków Homo habilis oraz Australopithecus boisei w rejonie wąwozu Olduvai oraz odciski stóp hominida (który przyjmował już postawę wyprostowaną) sprzed 3,6 milionów lat w rejonie Laetoli.

Krater Ngorongoro to największa niezniszczona i niezalana wodą taka forma na Ziemi. Jego ściany wznoszą się na 
wysokość prawie $1,5 \mathrm{~km}$ ponad dno ryftowej doliny i kilkaset metrów ponad dno kaldery.

Praca stanowi jedną z trzech publikacji poświęconych kraterowi Ngorongoro, będącemu największą atrakcją geoturystyczną ryftu Gregory'ego oraz jedną z największych osobliwości Wschodniej Afryki. Są one wynikiem półtoramiesięcznej wyprawy w te rejony, którą odbył w 2004 roku Jerzy Żaba. Jej celem była waloryzacja geostanowisk znajdujących się w rejonie ryftu Gregory'ego, ze szczególnym uwzględnieniem wulkanu Kilimandżaro (Żaba 2005) i rejonu Obszaru Chronionego Ngorongoro. Niniejsza praca, otwierająca cykl tych publikacji, została poświęcona uwarunkowaniom geograficznym Krateru, czyli: ukształtowaniu powierzchni terenu, warunkom hydrologicznym i klimatycznym, przyrodzie ożywionej oraz lokalnej autochtonicznej ludności. W pracy drugiej zaprezentowano pozycję strukturalną Krateru w obrębie wschodnioafrykańskiego systemu ryftowego oraz jego ewolucję geologiczną (Żaba, Gaidzik 2011a). Trzecia część tego cyklu dotyczy turystyki w tym regionie (wraz z wynikającymi stąd zagrożeniami) oraz atrakcji geoturystycznych (Żaba, Gaidzik 2011b).

\section{Położenie i ukształtowanie}

Krater Ngorongoro znajduje się w północnej Tanzanii, w prowincji Arusha, około $90 \mathrm{~km}$ na zachód od tej miejscowości, w pobliżu granicy z Kenią. Leży on na Wyżynie Wschodnioafrykańskiej, w jej części zwanej Wyżyną Kraterów (Fig. 2, 3). Obszar ten znajduje się na zachodnim, podniesionym skrzydle rowu tektonicznego o charakterze ryftu kontynentalnego noszącego na tym obszarze nazwę ryftu Gregory'ego. Rozciąga się on subpołudnikowo od jeziora Eyasi na południu po jezioro Natron na północy. Ku zachodowi Wyżyna Kraterów stopniowo przechodzi (poprzez skarpy uskokowe) w równiny Serengeti i Salei. Od wschodu jest ona ograniczona stromymi ścianami doliny ryftu Gregory’ego. Wyżyna Kraterów wznosi się średnio na wysokość około 2000 m n.p.m., zaś najwyższa kulminacja znajdująca się na wierzchołku wulkanu Loolmalasin ma wysokość 3648 m n.p.m. (Dawson 2008). W obrębie wyżyny znajduje się wiele różnej wielkości stożków wulkanicznych.

Krater Ngorongoro stanowi owalną kalderę wygasłego wulkanu tarczowego o średnicy około $35 \mathrm{~km}$. Szerokość równoleżnikowa kaldery wynosi $21 \mathrm{~km}$, natomiast południkowa $17,7 \mathrm{~km}$. Cały wulkan zajmuje powierzchnię $304 \mathrm{~km}^{2}$, zaś sama kaldera $-264 \mathrm{~km}^{2}$. Jest to największa tak dobrze zachowana kaldera wulkaniczna na kuli ziemskiej. Biorąc pod uwagę takie formy zalane wodą bądź częściowo zniszczone, można stwierdzi, że krater Ngorongoro zajmuje szóste miejsce na Ziemi (Pickering 1994).

Dno kaldery jest niemalże płaskie (Fig. 4). Najniższy punkt, znajdujący się w części południowej kaldery w pobliżu słonego jeziora Makat, ma wysokość około 1700 m n.p.m., z kolei najwyżej położona (1830 m n.p.m.; Pickering 1994) jest jej część północno-wschodnia (Fig. 5). Ściany kaldery wznoszą się kilkaset metrów (400-610 m) ponad jej dno oraz około $1400 \mathrm{~m}$ ponad dno sąsiadującej od wschodu doliny ryftowej. Wysokość bezwzględna kaldery waha się od 2280 do 2440 m n.p.m. (Pickering 1994).

W obrębie kaldery zaznacza się wiele pomniejszych form morfologicznych, stanowiących pewne urozmaicenie prze- ważnie płaskiej powierzchni jej dna (Fig. 6). Są to niewielkie wzgórza i pagórki wznoszące się na wysokość kilkudziesięciu metrów ponad dno kaldery, występujące głównie w części północnej i wschodniej. Należy do nich między innymi trzydziestometrowej wysokości wzgórze Engitati (1793 m n.p.m.; Tombazzi 2003) o średnicy 1,2 km, znajdujące się w północno-zachodniej części Krateru. W jego szczytowej części zaznacza się płytkie, owalne zagłębienie przypominające spodek. Do interesujących form tego typu należą też wzgórza Osilale (1827 m n.p.m.) oraz Rumbe (1914 m n.p.m.; Tombazzi 2003).

U podnóża ścian krateru także rozciągają się stosunkowo niewielkie wzniesienia, które w południowo-wschodniej części kaldery łączą się, tworząc bardzo charakterystyczne formy przypominające półki (np. wzgórza Keshei). Podobne struktury w części północnej tworzą kilka bardzo wyraźnych wzniesień o zarysach stożków (np. wzgórza Olkaria, 2023 m i 1931 m n.p.m.), (Fig. 5; Tombazzi 2003). Bardzo charakterystyczny pagórkowaty krajobraz występuje również w południowo-zachodniej części kaldery.

\section{Wody}

W obrębie krateru Ngorongoro występują wody zarówno płynące, jak i tworzące stałe zbiorniki o różnym charakterze. Znajdują się tu źródła, rzeki stałe i okresowe, bagna oraz zbiorniki wody słodkiej i słonej. Największym spośród tych ostatnich jest brakiczne jezioro Makat (Magadi; Fig. 5, 7), co w języku Masajów oznacza sól. Koncentracja jonów $\mathrm{Cl}^{-}$ w tym zbiorniku znacznie przekracza $100 \mathrm{mg} / \mathrm{l}$, zaś w porze suchej osiąga wartość ponad $3000 \mathrm{mg} / \mathrm{l}$. Wartość pH tej wody wynosi około 10 (Deocampo 2004). Jezioro to w zależności od pory roku znacznie zmienia zajmowaną powierzchnię. Podczas pory suchej nieraz całkowicie wysycha, pozostawiając po sobie bardzo płaską powierzchnię pokrytą solą. Natomiast w okresie pory deszczowej jego głębokość osiąga nawet $4 \mathrm{~m}$.

Drugim pod względem wielkości zbiornikiem położonym na południe od jeziora Makat jest znacznie mniejszy tzw. Basen Hipopotamów (Fig. 5, 7), w którym koncentracja jonów $\mathrm{Cl}^{-}$waha się w przedziale od 20 do $120 \mathrm{mg} / \mathrm{l}$, zaś wartość $\mathrm{pH}$ wynosi około 9 (Deocampo 2004).

W obrębie dna kaldery znajduje się ponadto wiele znacznie mniejszych jezior, które w większości całkowicie wysychają w porze suchej (Tombazzi 2003). Na dnie krateru występują również tereny bagienne skoncentrowane przede wszystkim w dwóch rejonach; są to bagno Mandusi (Munduusi) oraz bagno Gorigor, leżące kolejno na północ i na południe od jeziora Makat (Fig. 5). Bagna te rozciągają się równoleżnikowo na długości około $10 \mathrm{~km}$. Wartość $\mathrm{pH}$ wody w tych zbiornikach wynosi około 7-8, co świadczy, iż są one bardziej kwaśne od wód jeziornych tego obszaru (Deocampo 2004).

Ściany krateru, przede wszystkim w części północnej, są porozcinane przez głębokie doliny wyżłobione przez spływające z Wyżyny Kraterów stałe i okresowe potoki. Ze stoków wulkanu Olmoti do krateru Ngorongoro spływają: okresowa rzeka Layanai w części północno-zachodniej kaldery oraz stała rzeka Munge w części północno-wschodniej (Fig. 5). Obydwie te rzeki zasilają w wodę bagno Mandusi (Munduusi) oraz jezioro Makat. Przez wschodnią część 
krateru przepływa okresowa rzeka Oljoro Nyokie uchodząca do bagna Gorigor. W części południowo-zachodniej znajduje się kilka niewielkich cieków wodnych Endeani, Olawara, Lairatati, spływających z obrzeży krateru. Wszystkie one kończą się w Lesie Lerai. Wartość pH tych wód waha się przeważnie w granicach od 7 do 8, zaś zasolenie wzrasta w dół ich biegu, co wiąże się ze wzmożoną ewaporacją (Deocampo 2004).

Do największych źródeł krateru Ngorongoro należy Koitoktok (Ngoitokitok), którego wydajność przekracza 4,5 mln litrów dziennie (Fig. 5). Stanowi ono niezwykle istotny czynnik egzystencji Masajów, a w szczególności ich działalności pasterskiej. W zachodniej części krateru znajduje się źródło Seneto (Fig. 5). Wypływający z niego potok uchodzi do jeziora Makat. Wody źródeł w kraterze Ngorongoro cechują się najniższym zasoleniem; koncentracja jonów $\mathrm{Cl}^{-}$nie przekracza w nich zazwyczaj poziomu $10 \mathrm{mg} / \mathrm{l}$. Natomiast odczyn pH jest zbliżony do wartości charakterystycznych dla wód rzecznych na tym obszarze (Deocampo 2004).

\section{Klimat}

Klimat rejonu Ngorongoro jest silnie zróżnicowany $\mathrm{z}$ uwagi na znaczne deniwelacje terenu. Na obszarze tym zaznaczają się dwie pory roku: sucha trwająca od połowy maja do połowy listopada i deszczowa - przypadająca na pozostałą część roku. Na klimat lokalny bardzo silny wpływ wywierają znaczne deniwelacje pomiędzy dnem kaldery, a jej partiami szczytowymi. Na leżących znacznie wyżej obrzeżach krateru, a także w lasach porastających stoki kaldery, dominuje klimat wilgotny cechujący się mglistą pogodą (Fig. 9, 10). Natomiast na dnie kaldery przeważają półsuche równiny, gdzie temperatura w ciągu doby może się zmieniać w szerokich granicach od $2{ }^{\circ} \mathrm{C}$ do około $35^{\circ} \mathrm{C}$. Najobfitsze opady (800-1200 mm/rok) obejmują zalesione, strome, wschodnie ściany krateru, podczas gdy na znacznie mniej strome, zachodnie zbocza spada wyraźnie mniej wody deszczowej (400-600 mm/rok; UNESCO/IUCN 2008).

\section{Flora i fauna}

Krater Ngorongoro z uwagi na występujące w jego obrębie niespotykane bogactwo i różnorodność świata przyrodniczego (por. Tab. 1, 2) bywa określany jako „naturalna Arka Afryki”, „sanktuarium dzikiej przyrody Afryki”, a nawet „mikrokosmos Równin Serengeti”. Obszar ten jest wyjątkowy ze względu na bogactwo oraz różnorodność flory i fauny.

Ngorongoro leży w obrębie dwóch biogeograficznych prowincji Lasów Wschodniej Afryki oraz Sawanny. Jednakże $\mathrm{z}$ uwagi na znaczne zróżnicowanie lokalnego klimatu, związane $\mathrm{z}$ dużymi deniwelacjami terenu na obszarze tym można wyróżnić co najmniej kilka zazębiających się i wzajemnie nakładających ekosystemów (Fig. 11).

Strome ściany krateru Ngorongoro pokryte są zaroślami wrzosowymi, górskimi łąkami, wysokimi torfowiskami i pozostałościami gęstych, wiecznie zielonych górskich lasów równikowych (Fig. 11, 12). Na obszarach leśnych dominują drzewa z gatunków: Albizzia gummifera, Podocarpus latifolia, Acacia lahai, Hagenia abyssinica i Olea chrysophylla (Tab. 1). Partie ścian krateru pokryte roślinnością trawiastą cechują pojedyncze wystąpienia drzew z gatunku Euphorbia bussei (Estes et al. 2006). Szczególnie istotne dla ochrony dorzecza krateru Ngorongoro są wyżynne tereny leśne z gatunkami: Acacia lahai i Acacia seyal (Kayera 1988, vide UNESCO/IUCN 2008).

Dno krateru zajmują przede wszystkim równiny pokryte głównie niską roślinnością trawiastą (Fig. 11, 13) z gatunków: Hyparrenia ruta, Aristida kenyensis, Pennisetum mezianum, Chloris gayana, Themeda triandra, Cynodon dactilon oraz Digitaria macroblephara (Tombazzi 2003). Ponadto można tu wyróżnić słodkie i brakiczne jeziora, bagna, szuwary oraz dwa akacjowe obszary leśne: Las Lerai (Lerai Forest) z dominacją drzew z gatunków Acacia xanthophloea i Rauwolfia caffra oraz Las Laiyanai (Laiyanai Forest) z gatunkami Cassipourea malosana, Albizzia gummifera i Acacia lahai (Fig. 5, 11; UNESCO/IUCN 2008).

W obrębie krateru Ngorongoro żyje około 25000 dużych zwierząt, głównie kopytnych. Do najczęściej spotykanych gatunków należą: gnu (Connochaetes taurinus - wielkość populacji w roku 1994 była szacowana na około 7000 sztuk), zebry (Equus burchelli - 4000 sztuk; Fig. 16, 17), elandy (Taurotragus oryl), gazele Granta (Nanger granti, Gazella granti) i gazele Thompsona (Eudorcas thomsonii). Ponadto bardzo powszechnie są spotykane: bawoły afrykańskie (Syncerus caffer; Fig. 18), bawolce (Alcelaphus buselaphus) oraz guźce (Phacochoerus africanus) (UNESCO/IUCN 2008). Populacje poszczególnych gatunków osiągają niekiedy liczebności około 5000 osobników, zwłaszcza podczas pory suchej (Tab. 2). Idealne warunki do życia zwierzęta te zawdzięczają występowaniu licznych pastwisk w obrębie krateru, a także stałemu dostępowi do czystej, słodkiej wody (Fig. 11).

Występowanie bagien oraz lasów zapewnia doskonałe warunki do życia dla takich gatunków zwierząt jak hipopotamy (Hippopotamus amphibius; Fig. 19), redunce (Redunca), buszboki (Tragelaphus scriptus), pawiany (Papio), słonie afrykańskie (Loxodonta africana; Fig. 20) oraz serwety (koczkodany tumbili; Chlorocebus pygerythrus, Cercopithecus pygerythrus) (http://www.ngorongorocrater.org/welcome. html). Kob śniady (kobus; Kobus ellipsiprymnus) pojawia się natomiast głównie w pobliżu Lasu Lerai.

W kraterze Ngorongoro występują nie tylko zwierzęta roślinożerne. Zamieszkujące te tereny drapieżniki należą głównie do rodziny kotowatych. Zdecydowanie najwięcej jest lwów (Panthera leo), których populację w roku 2001 oszacowano na 62 osobniki (Fig. 21; Kangera 2002). Z uwagi na stosunkowo niewielką powierzchnię kaldery obszar ten charakteryzuje się największą znaną na kuli ziemskiej gęstością występowania tego drapieżnika. Oprócz dominujących liczebnie lwów żyją tu również lamparty (Panthera pardus), serwale (Leptailurus serval) oraz znacznie rzadsze gepardy (Acinonyx jubatus). W lasach Ngorongoro odnotowano w ostatnich latach (według raportu UNESCO) również obecność afrykańskiego kota złocistego (Profelis aurata; UNESCO/IUCN 2008). Ponadto pojawiają się średniej wielkości stada hien (Hyaeninae; Fig. 22), głównie hieny cętkowanej (Crocuta crocuta) oraz różne gatunki szakali (Tab. 2): czaprakowego (Canis mesomelas), złocistego (Canis aureus) i pręgowanego (Canis adustus). Jeszcze do niedawna w kraterze notowano również obecność likaona (simira; Lycaon 
pictus), niestety w ostatnim czasie jego populacja znacznie się w tym rejonie zmniejszyła (UNESCO/IUCN 2008).

Jednakże najbardziej znanym i w największym stopniu zagrożonym gatunkiem krateru Ngorongoro jest nosorożec czarny (Diceros bicornis), który znajduje się w Czerwonej Księdze Gatunków Zagrożonych Wyginięciem (http://www. iucnredlist.org/). Jego populacja na tym obszarze pomimo działań ochronnych znacząco spadła $\mathrm{z}$ poziomu ponad 100 osobników w latach 1964-1966 do zaledwie kilkunastu (11-14) w roku 1995 (Moehlman et al. 1996). Obecnie ich sytuacja się stabilizuje, są one stosunkowo bezpieczne i ich liczebność ponownie przekroczyła 20 sztuk (http://www. ngorongorocrater.org/welcome.html).

W obrębie krateru Ngorongoro i obszarów przyległych odnotowano występowanie ponad 500 gatunków ptaków. Najbardziej liczna w kraterze Ngorongoro jest populacja flamingów (Fig. 23) zasiedlających jezioro Makat. Są to przede wszystkim dwa gatunki: czerwonak (Phoenicopterus ruber) oraz flaming mały (Phoenicopterus minor). Do pozostałych większych ptaków żyjących w kraterze należą: strusie (Struthio camelus; Fig. 24) oraz pelikany różowe (Pelicanus onocrotalus). Tereny bagienne (np. bagno Gorigor bądź bagno Mandusi) są bardzo chętnie odwiedzane przez czaple modronose (Ardeola ralloides), warzęchy czerwonolice (Platalea alba), ibisy czczone (Threskiornis aethiopicus), cyraneczki płowe (Anas capensis), sterniczki afrykańskie (Oxyura maccoa), wodniki afrykańskie (Rallus caerulescens), szablodzioby (Recurvirostra avosetta), rybitwy białowąse (Chlidonias hybridus) i mewy szarogłowe (Larus cirrocephalus).

Spośród innych gatunków ptaków żyjących w kraterze Ngorongoro szczególnie często bywa spotykany: bocian białobrzuchy (Ciconia abdimi), bocian biały (Ciconia ciconia), dławigad afrykański (Mycteria ibis), orłosęp brodaty (Gypaetus barbatus), sęp plamisty (Gyps rueppellii), orzeł czarny (Aquila verreauxii), ścierwnik (ścierwnik biały, białosęp; Neophron percnopterus), błotniak stepowy (b. blady, b. biały) (Circus macrourus), pustułeczka, sokół pustułeczka, dzwonniczek pustułeczka, białoszpon (Falco naumanni), sokół maskowy (Falco fasciinucha), drop olbrzymi (Ardeotis kori syn. Choriotis kori), dubelt (Gallinago media), nierozłączka rudogłowa (Agapornis fischeri), dzięcioł brązowogrzbiety (Picoides obsoletus crateris), wrona przylądkowa (Corvus capensis), szponnik różowogardły (Macronyx ameliae), nikornik białosterny (Apalis karamojae), chwastówka górska (Cisticola hunteri), sikora rdzawoszyja (Parus fringillinus) i baletnik (Euplectes jacksoni). Ponadto krater zamieszkują niewielkie ptaki głównie dwóch gatunków z rodziny nektarników (sunbirds, Nectariniidae): nektarnik złocisty (Cinnyris reichenowi syn. Nectarinia reichenowi) i nektarnik dwuwstęgi (Cinnyris mediocris syn. Nectarinia mediocris). Żywiąc się przede wszystkim nektarem, zajmują one tę samą niszę ekologiczną co kolibry w Ameryce (UNESCO/IUCN 2008).

Należy zaznaczyć, że w kalderze nie występują niektóre gatunki zwierząt często kojarzone z Afryką, które można obserwować jedynie na obrzeżach krateru lub w innych rejonach Wyżyny Kraterów; są to np.: impala (Aepyceros melampus), topi, sassebi (Damaliscus lunatus), oribi (Ourebia ourebi), żyrafa (Fig. 25; Giraffa camelopardalis) oraz krokodyl nilowy (Crocodylus niloticus).

\section{Masajowie - autochtoniczna ludność krateru Ngorongoro}

Ludność autochtoniczną rejonu krateru Ngorongoro stanowi półkoczownicza grupa etniczna Masajów, którzy zasiedlili krater Ngorongoro około roku 1840. Po powstaniu Obszaru Chronionego Ngorongoro liczba ludności masajskiej zamieszkującej te tereny zaczęła gwałtownie rosnąć, osiągając w roku 1966 w samym kraterze liczbę prawie dziewięciu tysięcy mieszkańców. Jednak od 1974 roku w Ngorongoro nie ma już ani jednego stałego mieszkańca. Ludność masajska zamieszkuje obrzeżenia krateru oraz inne części Obszaru Chronionego Ngorongoro. Szacuje się, iż na terenie północnej Tanzanii i południowej Kenii żyje obecnie niemalże 900 tysięcy Masajów (UNESCO/IUCN 2007).

Ludność masajska trudni się przede wszystkim pasterstwem (Fig. 26). Pogłowie bydła hodowanego przez Masajów jest oceniane na około 300 tys. sztuk. Część z nich jest wypasanych również w obrębie krateru Ngorongoro i na innych obszarach NCA. Z uwagi na półkoczowniczy tryb życia Masajowie budują jedynie prowizoryczne domy z lokalnych materiałów. Wioski są otoczone płotem w kształcie okręgu, który jest budowany przez mężczyzn, zazwyczaj z ciernistej akacji (Fig. 27). Jej członkowie posługują się językiem Maa (por. Tab. 1) i charakteryzują się stosunkowo wysokim wzrostem jak na mieszkańców Afryki. Bardzo popularne wśród Masajów jest przekłuwanie i rozciąganie małżowin usznych (Fig. 28). W ubiorze ludność ta zdecydowanie preferuje różne odcienie barwy czerwonej (Fig. 29). Tradycyjnie masajska dieta składa się z mięsa, mleka i krowiej krwi. Szczególnie charakterystyczny jest obrzęd wyboru nowego władcy danej wioski. Zwycięzcą tych jedynych w swoim rodzaju wyborów jest ten, kto potrafi najwyżej podskakiwać (Fig. 30).

\section{Podsumowanie}

Krater Ngorongoro odznacza się wyjątkowo dużymi, unikalnymi w skali światowej walorami przyrodniczymi i co za tym idzie turystycznymi. Połączenie bogactwa przyrody ożywionej, zarówno świata roślinnego, jak i zwierzęcego, z niewątpliwą egzotyką kultury masajskiej oraz majestatycznymi krajobrazami sprawia, iż krater jest miejscem bardzo chętnie odwiedzanym przez turystów z całego świata. Świat przyrodniczy jest na tyle bogaty, różnorodny i samowystarczalny, iż przywodzi na myśl „Zaginiony Świat” opisany przez Sir Arthura Conan Doyle'a. Brak w kraterze niektórych z charakterystycznych dla Afryki zwierząt, np. żyrafy, jest rekompensowany przez wiele endemicznych tudzież rzadkich gatunków zwierząt, często zagrożonych wyginięciem (np. przez nosorożca czarnego).

O wyjątkowej atrakcyjności tego obszaru świadczy stopień i charakter jego ochrony oraz zagospodarowania turystycznego. W 1959 roku, w celu ochrony tej wyjątkowej atrakcji geoturystycznej, a także innych znajdujących się w okolicy wygasłych tarczowych wulkanów, utworzono Obszar Chroniony Ngorongoro (NCA). Z uwagi na bogactwo i różnorodność świata zwierzęcego i roślinnego, szczególne przejawy bardzo istotnych dla rozwoju Ziemi procesów geologicznych oraz wybitne wartości kulturowe związane z ewolucją ludzkości krater został wpisany na Listę Światowego Dziedzictwa Kulturowego i Przyrodniczego UNESCO (jako obiekt mieszany). Krater Ngorongoro znajduje się również w obrębie 
Rezerwatu Biosfery utworzonego w ramach programu UNESCO Człowiek i Biosfera, a także światowego Obszaru Ptaków Endemicznych oraz Światowych Ekoregionów Słodkiej Wody WWF. Ponadto w niewielkiej odległości od kra- teru Ngorongoro znajduje się kolejna bardzo ważna atrakcja geoturystyczna, najwyższa góra Afryki: wulkan Kilimandżaro (Żaba 2005).

\section{References (Literatura):}

Anderson, G., Herlocker, D., 1973. Soil factors affecting the distribution of the vegetation types and their utilization by wild animals in Ngorongoro Crater, Tanzania. Journal of Ecology, 61: 627-651.

Dawson, J.B., 2008. The Gregory Rift Valley and Neogene-Recent Volcanoes of Northern Tanzania. Geological Society, London, $102 \mathrm{pp}$.

Deocampo, D., 2004. Hydrogeochemistry in the Ngorongoro Crater, Tanzania, and the implications for land use in a World Heritage Site. Applied Geochemistry, 19: 755-767.

Deocampo, D., Ashley, G., Copeland, S., 1998. Springs and Streams in an East African Closed Basin: Controls on Biological Communities in Ngorongoro Crater, Tanzania. GSA Abstract Programme, 30, p. 120.

Estes, R.D., Atwood, J.L., Estes, A.B., 2006. Downward trends in Ngorongoro Crater ungulate populations 1986-2005: Conservation concerns and the need for ecological research. Biological Conservation, 131 106-120.

Estes, R.D., Small, M., 1981. The large herbivore populations of Ngorongoro Crater. African Journal of Ecology, 19: 175-185.

Fishpool, L., Evans, M. (eds.), 2001. Important Bird Areas for Africa and Associated Islands. Priority Sites for Conservation. Pisces Publications and Birdlife International, Newbury and Cambridge, U.K. BLI Conservation Series No.11.

Kangera, R., 2002. Time, life and tides in Ngorongoro Park. Arusha Times, 31 May, Arusha.

Moehlman, P., Amato, G., Runyoro, V., 1996. Genetic and demographic threats to the black rhinoceros population in the Ngorongoro Crater. Conservation Biology, 10 (4): 1107-1114.
Pickering, R., 1994. Ngorongoro's Geological History. Ngorongoro Conservation Area Authority, Arusha, $52 \mathrm{pp}$.

Said, M., Chunge, R., Craig, G., Thouless, C., Barnes, R., Dublin H., 1995. African Elephant Database, 1995. IUCN, Gland, Switzerland, 225 pp.

Tombazzi, G., 2003. New map of Ngorongoro Conservation Area. Maco Editions LLC, Italy.

UNESCO/IUCN, 2007. Ngorongoro Conservation Area (United Republic Of Tanzania). Report of the WHC / IUCN Reactive Monitoring Mission May 2007.

UNESCO/IUCN, 2008. Ngorongoro Conservation Area (United Republic Of Tanzania). Report of the WHC / IUCN Reactive Monitoring Mission May 2008.

Żaba, J., 2005. The Kilimanjaro Volcano - geotouristic attraction in Africa. Geotourism, 1 (2): 3-12.

Żaba, J. Gaidzik, K., 2011a. The Ngorongoro Crater as the biggest geotouristic attraction of the Gregory Rift (Northern Tanzania, Africa) - geological heritage. Geotourism, 1-2 (24-25): 27-46.

Żaba, J., Gaidzik, K., 2011b. The Ngorongoro Crater as the biggest geotouristic attraction of the Gregory Rift (Northern Tanzania, Africa) - geotouristic valorization, touristic development and hazard. Geotourism, 1-2 (24-25): 47-64.

Websites:

http://earthobservatory.nasa.gov/IOTD/view.php?id=4705

http://earthobservatory.nasa.gov/Newsroom/NewImages/images. php3?img_id=17196

http://www.ngorongorocrater.org/welcome.html

http://www.iucnredlist.org/ 